\title{
СТРАТИГРАФИЯ, ЛИТОЛОГИЯ И ГЕОХИМИЯ ПРИБРЕЖНО- И МЕЛКОВОДНО-МОРСКИХ РАЗРЕЗОВ ВЕРХОВ СРЕДНЕЙ ЮРЫ - НИЗОВ МЕЛА Р. АНАБАР (АРКТИЧЕСКАЯ СИБИРЬ)
}

\author{
Никитенко Б. Л., Девятов В. П., Пещевицкая Е. Б., Попов А. Ю., Фурсенко Е. А., Хафаева С. Н.
}

\begin{abstract}
Аннотация
Представления о стратиграфии прибрежно- и мелководно-морских разрезов верхов средней юры и низов мела, вскрытых на правобережье р. Анабар неоднократно кардинально изменялись. Проведенные исследования и анализ опубликованных данных нацелены на уточнение био- и литостратиграфического расчленения разреза, обоснование его стратиграфической полноты, детальное и комплексное описание выделенных стратонов. Комплексные биостратиграфические исследования разреза верхов бата - низов бореального берриаса позволили выявить последовательности из девяти биостратонов в ранге зон и слоев с диноцистами и с палинофлорой. Часть палинологических биостратонов установлена впервые. В исследованных разрезах прослежены фораминиферовые комплексы зон бореального стандарта. Полученные новые биостратиграфические данные и анализ всех известных находок аммонитов позволили обосновать стратиграфическую непрерывность Анабарского разреза, несмотря на сокращенную мощность стратиграфических подразделений. Уточнено стратиграфическое положение границы между содиемыхаинской и буолкалахской свитами. В предлагаемой интерпретации базальный горизонт буолкалахской свиты фиксирует новый крупный этап осадконакопления в конце оксфорда - начале кимериджа, прослеживаемый как нижняя граница разноранговых литостратонов по всему Арктическому и частично Бореальному регионам. Впервые толща охарактризована литогеохимическими параметрами. Содержание Сорг в исследованных образцах свит не превышает его кларковых значений, а пиролитический показатель Ттах свидетельствует о низкой зрелости органического вещества и невысоком нефтегазогенерационном потенциале. Исследованное органическое вещество пород характеризуется тяжелым изотопным составом углерода, что позволяет предполагать его преимущественно террагенный генотип.
\end{abstract}

\section{Ключевые слова:}

Верхняя юра и нижний мел, стратиграфия, Арктическая Сибирь, р. Анабар, фораминиферы, цисты динофлагеллят, споры и пыльца, литогеохимия, органическая геохимия 


\title{
СТРАТИГРАФИЯ, ЛИТОЛОГИЯ И ГЕОХИМИЯ ПРИБРЕЖНО- И МЕЛКОВОДНО-МОРСКИХ РАЗРЕЗОВ ВЕРХОВ СРЕДНЕЙ ЮРЫ - НИЗОВ МЕЛА Р. АНАБАР (АРКТИЧЕСКАЯ СИБИРЬ)
}

\author{
Б.Л. Никитенко ${ }^{1,2}$, В.П. Девятов ${ }^{3}$, Е.Б. Пещевицкая ${ }^{1}$, А.Ю. Попов ${ }^{1,2}$, \\ Е.А. Фурсенко ${ }^{1,2}$, С.Н. Хафаева ${ }^{1}$ \\ ${ }^{1}$ Институт нефтегазовой геологии и геофизики им. А.А. Трофимука СО РАН, \\ 630090, Новосибирск, просп. академика Коптюга, 3, e-mail: NikitenkoBL@ipgg.sbras.ru \\ ${ }^{2}$ Новосибирский национальный исследовательский государственный университет, \\ 630090, Новосибирск, ул.Пирогова, 2 \\ ${ }^{3}$ АО “Сибирский научно-исследовательский институт геологии, геофизики и минерального сырья", \\ 630091, Новосибирск, Красный проспект, 67
}

\begin{abstract}
Представления о стратиграфии прибрежно- и мелководно-морских разрезов верхов средней юры и низов мела, вскрытых на правобережье р. Анабар неоднократно кардинально изменялись. Проведенные исследования и анализ опубликованных данных нацелены на уточнение био- и литостратиграфического расчленения разреза, обоснование его стратиграфической полноты, детальное и комплексное описание выделенных стратонов. Комплексные биостратиграфические исследования разреза верхов бата - низов бореального берриаса позволили выявить последовательности из девяти биостратонов в ранге зон и слоев с диноцистами и с палинофлорой. Часть палинологических биостратонов установлена впервые. В исследованных разрезах прослежены фораминиферовые комплексы зон бореального стандарта. Полученные новые биостратиграфические данные $и$ анализ всех известных находок аммонитов позволили обосновать стратиграфическую непрерывность Анабарского разреза, несмотря на сокращенную мощность стратиграфических подразделений. Уточнено стратиграфическое положение границы между содиемыхаинской и буолкалахской свитами. В предлагаемой интерпретации базальный горизонт буолкалахской свиты фиксирует новый крупный этап осадконакопления в конце оксфорда - начале кимериджа, прослеживаемый как нижняя граница разноранговых литостратонов по всему Арктическому и частично Бореальному регионам. Впервые толща охарактризована литогеохимическими параметрами. Содержание Сорг в исследованных образцах свит не превышает его кларковых значений, а пиролитический показатель $\mathrm{T}_{\text {max }}$ свидетельствует о низкой зрелости органического вещества и невысоком нефтегазогенерационном потенциале. Исследованное органическое вещество пород характеризуется тяжелым изотопным составом углерода, что позволяет предполагать его преимущественно террагенный генотип.
\end{abstract}

Верхняя юра и нижний мел, стратиграфия, Арктическая Сибирь, р. Анабар, фораминиферы, цисты динофлагеллят, споры и пыльца, литогеохимия, органическая геохимия

\section{ВВЕДЕНИЕ}

Стратиграфические исследования юры и мела Арктической Сибири сконцентрированы, в первую очередь, на непрерывных, стратиграфически наиболее полных разрезах, сформировавшихся в обстановках, удаленных от берега или умеренно глубоководных и охарактеризованных многочисленными находками разных групп фоссилий [Стратиграфия..., 1976; Шурыгин и др., 2000; Никитенко и др., 2013; 2015а,б]. Разрезы же, образовавшиеся в условиях крайнего мелководья, переходные от субконтинентальных к мелководно-морским, с многочисленными следами размывов и перерывов, спорадическим распределением комплексов фоссилий, обычно были малоинтересны для разработки зональной стратиграфии. Вместе с тем для непротиворечивых палеогеографических и биофациальных реконструкций важна точная и высокоразрешающая стратиграфическая основа в разрезах разного типа. Прибрежные и мелководные разрезы построены наиболее контрастно и несут важную информацию для реконструкции геологических событий разного ранга и восстановления наиболее полной 
истории регионов. К таким разрезам относятся естественные выходы верхов средней юры - низов мела, вскрытые на правом берегу р. Анабар (север Средней Сибири), в междуречье рр. Средняя - Содиемыха (рис. 1). Несмотря на длительное изучение этих разрезов [Толль, 1899; Павлов, 1914; Бодылевский, 1960; Сакс и др., 1963; Стратиграфия..., 1976; Опорный разрез..., 1981; Никитенко и др., 2013], представления об их стратиграфии неоднократно кардинально трансформировались. Например, по результатам изучения аммонитов рядом исследователей установлена нижняя часть келловея [Толль, 1899; Павлов, 1914; Духанин, 1976а], другими указывалось присутствие исключительно самых верхов келловея, с размывом залегающего на бате [Сакс и др., 1963; Стратиграфия..., 1976; Князев, 1975; Меледина, 1977; Решения..., 1981]. По-разному трактовалось стратиграфическое положение глинистой толщи низов современной буолкалахской свиты: одни специалисты полагали, что это средняя часть берриаса [Сакс и др., 1963; Духанин, 1976а; Опорный разрез..., 1981; Решения..., 1981], другие же датировали этот уровень как волжский [Стратиграфия..., 1976; Месежников, 1984]. В этих разрезах, по данным анализа последовательностей находок аммонитов, на разных уровнях фиксировался ряд крупных стратиграфических несогласий. Причем, микропалеонтологические и палинологические исследования были фрагментарными и проводились, обычно, на определенных стратиграфических уровнях [Сакс и др., 1963; Решения..., 1981; Опорный разрез..., 1981; Лутова, 1981]. В результате, чего полученные данные не могли быть в полной мере использованы для решения ряда спорных моментов.

Восполняя этот пробел в изучении микрофоссилий и разрешении изложенных противоречий, в 2013 г. авторами были проведены детальные комплексные исследования естественных выходов юры и мела на правом берегу р. Анабар, в междуречье рр. Средняя - Содиемыха (рис. 1, 2). На протяжении более 25 км слои горных пород, обнаженные в береговых обрывах высотой до 50 м, слабо ундулируя, погружаются в северном направлении под углом менее одного градуса. В изученном разрезе по единой методике выполнен весь необходимый комплекс биостратиграфических, литостратиграфических и седиментологических исследований юрюнгтумусской (бат), содиемыхаинской (верхи бата - низы верхнего оксфорда) и буолкалахской (верхи оксфорда - бореальный берриас) свит. Проведенные исследования $и$ анализ прежних находок макрофауны нацелены на уточнение био- и литостратиграфического расчленения разреза, обоснование его стратиграфической полноты, детальное и комплексное описание выделенных стратонов. Наряду с анализом полевых материалов это позволит уточнить геологическое строение района и усовершенствовать геологическую карту на данном участке.

Изученный разрез верхов средней юры и низов мела на р. Анабар (рис. 1, 2) обладает рядом реперных, четко опознаваемых уровней, поэтому находки раковин аммонитов, произведенные ранее, надежно с ним увязываются. Публикации предшественников освещают хорошо обнаженные естественные выходы верхов средней юры и низов мела в районе р. Содиемыха [Бодылевский, 1960; Сакс и др., 1963; Стратиграфия..., 1976; Меледина, 1977; Опорный разрез..., 1981; Лутова, 1981; Месежников и др., 1989] и более южные разрезы, расположенные ближе к р. Половинная [Князев и др., 1973; 2017; Князев, 1975]. 
Ниже изложены результаты комплексных стратиграфических, литологических и геохимических исследований разреза верхов юрюнгтумусской, содиемыхаинской и низов буолкалахской свит (батский ярус - бореальный берриас).

\section{МАТЕРИАЛ И МЕТОДИКА ИССЛЕДОВАНИЙ}

Микропалеонтологический анализ проведен для 31 образца обнажения А9 и 27 образцов обнажения OK/S2 из верхов юрюнгтумусской, содиемыхаинской и низов буолкалахской свит (рис. 1, 2). При изучении микрофауны использовалась 200-граммовая навеска породы. Для дезинтеграции образцы предварительно многократно замораживались и размораживались в воде в морозильной камере, а затем кипятились и отмывались под струей воды через сито с диаметром ячеи 56 мкм. При подготовке образцов на палинологический анализ разреза А9 использовалась обработка соляной и плавиковой кислотами и центрифугирование в тяжелой кадмиевой жидкости с удельным весом 2,25. Процентное соотношения палиноморф в образце высчитывалось минимум от 200 зерен (сначала соотношение наземных и морских, затем от 200 в каждой группе отдельно). Более подробно методы подготовки образцов к микропалеонтологическому и палинологическому анализам и основные методические приемы, используемые для биостратиграфического анализа рассмотрены в работах [Nikitenko et al., 2008; Никитенко, 2009; Пещевицкая, 2010; Никитенко и др., 2013, 2015а, б].

Исследования по органической геохимии включали определения содержания Сорг и пиролитических характеристик $\left(\mathrm{S}_{1}, \mathrm{~S}_{2}, \mathrm{~T}_{\mathrm{max}}\right)$ органического вещества пород, которые выполнены методами, подробно описаны ранее [Никитенко и др., 2020]. Информация об изотопном составе углерода органического вещества $\left(\delta^{13} C_{\text {орг }}\right)$ недебитуминизированных бескарбонатных остатков пород разреза OK/S2 получена в ИГМ CO PAH (г. Новосибирск) с использованием масс-спектрометрического комплекса, состоящего из масс-спектрометра Finnigan MAT 253 и линии пробоподготовки Gas Bench II (Thermo Electron Corporation). Значения $\delta^{13} C_{\text {орг }}$ для проб разреза А9 определялись на масс-спектрометре DELTA V Advantage (ThermoFisher) в Томском филиале АО "СНИИГГиМС" (г. Томск). Погрешность полученных значений величин $\delta^{13} C_{\text {орг }}$ находилась на уровне $\pm 0,1$ (по стандартам) и менее $\pm 0,25 \%$ (для образцов).

Петрографические исследования терригенных пород проводились путем изучения 26 шлифов в поляризационном микроскопе Olympus BX60. Валовый химический состав пород (23 образца) исследован методами РФА и ИСП-МС в ИГМ СО РАН. Определение содержания основных породообразующих окислов проведено на рентгенофлуоресцентном спектрометре ARL-9900-XP (Thermo Electron Corporation). Определение содержания элементов-примесей проводилось на Исп масс-спектрометре высокого разрешения ELEMENT (Finnigan MAT, Germany).

\section{РЕЗУЛЬТАТЫ ПРЕДЫДУЩИХ СТРАТИГРАФИЧЕСКИХ ИССЛЕДОВАНИЙ РАЗРЕЗОВ ВЕРХОВ СРЕДНЕЙ ЮРЫ И НИЗОВ МЕЛА Р. АНАБАР}

Первые сведения о биостратиграфии верхов средней и верхней юры, низов мела р. Анабар были получены экспедицией Э.В. Толля [1894, 1899], собравшей богатые коллекции аммонитов. Результаты исследований этой экспедиции позволили получить первые представления о геологическом строении региона. Предварительный анализ 
таксономического состава аммонитов, проведенный А.О. Михальским [Толль, 1899] дал возможность обосновать на р. Анабар присутствие нижнего оксфорда и нижнего валанжина. Более поздние и детальные монографические исследования собранной коллекции фоссилий [Павлов, 1914] показали, что в этом разрезе присутствует нижний келловей (зона Cadoceras elatmae), нижний, средний и верхний (в современном понимании) оксфорд (рис. 3). Тем не менее, было высказано предположение [Сакс и др., 1963], основанное на опечатке в номере образца при описании нижнемелового аммонита в работе А.П. Павлова [1914], что находка Cadoceras elatmae происходит из другого местонахождения. Такой вывод был сделан еще и на том основании, что за этот период исследований, типичных нижнекелловейских аммонитов на р. Анабар больше не находили. В последующем, правильность определения этого нижнекелловейского аммонита [Павлов, 1914] как Cadoceras elatmae были подтверждены В.И. Бодылевским [1960], Н.С. Воронец [1962] и С.В. Мелединой [1977] при монографических исследованиях сибирских аммонитов. Несмотря на то, что найденные аммониты келловея и оксфорда не имели привязок к разрезу, собранные и опубликованные коллекции имеют важное значение и поныне.

Первое послойное описание Анабарского разреза было выполнено в 1936 г. С.И. Киселевым и опубликовано в обзорной статье В.И. Бодылевского [1960]. Несмотря на схематичность описания разреза, находки фоссилий хорошо увязываются с современными данными. Так, в разрезах приустьевой части р. Содиемыха (обн. 92 и 93, слой 2 по С.И. Киселеву) в оолитовых песчаниках (уровень слоя 6, обн. А9) были определены Cadoceras cf.stenolobum, Longaeviceras sp. и L. aff. nikitini и отнесены к верхнему келловею [Бодылевский, 1960] (рис. 3). В осыпи обнажения были собраны многочисленные нижнеи среднеоксфордские Cardioceras spp. В современной интерпретации вид Cadoceras cf.stenolobum рассматривается в объеме среднекелловейского рода Rondiceras и характеризует верхи среднего келловея [Князев и др., 2020]. Представители Longaeviceras типичны для верхнего келловея, но ряд специалистов [Киселев, 2006] не исключает их появление в верхах среднего келловея.

Позднее [Сакс и др., 1963], в этом местонахождении в серо-зеленых оолитовых песчаниках (обн. А9, слой 6) находили: Cadoceras ? (Longaeviceras ?) sp., Longaeviceras keyserlingi, L. ex gr. keyserlingi, отнесенных к верхнему келловею. Предполагалось, что нижний (в современном понимании) и средний келловей там отсутствуют. В разрезах, несколько выше по течению р. Анабар, в более высоких слоях, была собрана богатая коллекция нижне- и среднеоксфордских аммонитов, содержащая большинство характерных видов аммонитовых зон современной зональной шкалы. Отсутствие фоссилий верхов оксфорда, кимериджа и нижней половины волжского яруса дало возможность предположить там наличие крупного стратиграфического перерыва. Маломощные (0.3-1 м) зеленовато-серые глауконитовые пески с фосфоритами с неопределимыми аммонитами и многочисленными белемнитами были отнесены к верхневолжскому подъярусу. В то же время, на притоках р.Анабар этот горизонт увеличивается в мощности до 5 м и содержит средне- и верхневолжские фоссилии [Сакс и др., 1963]. Вышележащие глинисто-алевритистые образования с аммонитами Paracraspedites рассматривались как низы мела (=бореальный берриас) (рис. 3). 
В конце 60-х и 70-х годов прошлого века на севере Средней Сибири и, в частности, на р. Анабар, проводились активные стратиграфические исследования юры и мела: разрабатывались и совершенствовались зональные шкалы по аммонитам. Так, например, было существенно усовершенствованно зональное расчленение верхнего келловея и впервые обособлена его терминальная зона - Quenstedtoceras (Eboraciceras) subordinarium, прослеженная в разрезе на р. Анабар [Князев и др., 1973; Князев, 1975]. Проведенные детальные исследования аммонитов этого разреза позволили установить непрерывную последовательность аммонитовых зон верхов келловея - низов среднего оксфорда, ставшую эталонной [Князев и др., 1973; Князев, 1975]. Впервые в Анабарском разрезе по анализу изображенной А.П. Павловым [1914] коллекции аммонитов, собранной экспедицией Э.В. Толля [1894, 1899], был обоснован верхний оксфорд (Amoeboceras (Prionodoceras) kostromense) в современном понимании [Князев, 1975] (рис. 3). Следует отметить, что по сборам В.Г. Князева [1975] находки верхнекелловейских Quenstedtoceras (Eboraciceras) subordinarium и Qu. (Eb.) ordinarium постоянно сопровождались Qu. (Eb.) innocentii. По последним данным этот вид относится к роду Protolongaeviceras и рассматривается как среднекелловейский [Князев и др., 2020].

Исследования аммонитов в разрезах правобережья р. Анабар [Стратиграфия..., 1976] выявили в 4 км выше устья р. Содиемыха, кроме находок Longaeviceras, ядра аммонитов различной сохранности: Eboraciceras cf. subordinarium, E. subordinarium, Quenstedtoceras (Soaniceras) и др. Позднее [Меледина, 1977 и др.] из этого местонахождения приводились только находки Eboraciceras subordinarium, E.cf. subordinarium, E. sp.ind., Quenstedtoceras (Soaniceras) angustatum, Qu.(S.) parvulum, Vertumniceras nikitinianum, уже без упоминания представителей Longaeviceras (рис. 3). Таким образом, формировались представления, о том, что в Анабарском разрезе присутствуют только самые верхи верхнего келловея. В ходе полевых исследований авторами зональных шкал [Князев и др., 1973; Князев, 1975; Стратиграфия..., 1976; Меледина, 1977] находок типично средне- и нижнекелловейских аммонитов в изученных разрезах сделано не было и по-прежнему предполагался значительный стратиграфический перерыв между верхами бата и верхами келловея (рис. 3).

Следует отметить, что в эти годы проводились первые детальные исследования фораминиферовых комплексов келловея и нижнего оксфорда Анабарского разреза [Лутова, 1976; 1981]. Эти работы позволили проследить в разрезах устья р. Содиемыха комплекс фораминифер, который по современным данным, характерен для нерасчлененных зон Ammobaculites igrimensis JF31/Conorboides taimyrensis JF32 (верхи среднего - верхний келловей), т.е. не исключались и более низкие уровни келловея.

В конце 60-х годов прошлого века в районе среднего течения р. Анабар, где расположены и изученные, проводилось геологическое картирование масштаба 1 : 200 000 Анабарской партией НИИГА [Духанин, 1976а, б]. Определения аммонитов и двустворок из собранных коллекций (келловей, волжский ярус и бореальный берриас) выполнено Е.С. Ершовой. По ее данным, в изученных разрезах были найдены нижнекелловейский Cadoceras falsum, и Cadoceras tenuicostatum, характерный для среднего келловея Аляски. Несколько выше определялись верхнекелловейские 
Longaeviceras ex gr. nikitini (рис. 3). Полученные биостратиграфические данные предполагали стратиграфическую полноту келловейской части Анабарского разреза, однако в последующих построениях они не были учтены [Стратиграфия..., 1976; Решения..., 1981 и др.]. По данным В.Г. Князева [Духанин, 1976а] находки Quenstedtoceras (Eboraciceras) innocentii и Qu. (Eb.) subordinarium уже интерпретировались как нижнеоксфордские.

Реперный пласт глауконитовых песчаников с конкрециями фосфоритов $и$ белемнитами был отнесен к волжскому ярусу на основании находок в вышележащей части разреза нижневолжских аммонитов Pectinatites tenuicostus [Духанин, 1976а]. Перекрывающие их глины и алевриты с Subcraspedites spp. были отнесены к берриасу (рис. 3).

Этот крупный этап исследований завершился разработкой региональных стратиграфических схем мезозоя Средней Сибири [Решения..., 1981], где рассматривалось био- и литостратиграфическое расчленение мезозоя разных районов.

Нижняя часть разреза р. Анабар характеризовалась юрюнгтумусской свитой с аммонитами Arcticoceras ishmae (средняя часть бата) в верхней части (рис. 3). Предполагалось, что юрюнгтумусская свита трансгрессивно, с крупным стратиграфическим перерывом, перекрывается песчаными образованиями сиговской свиты, которая первоначально была выделена на северо-востоке Западной Сибири [Решения..., 1969; 1981] (рис. 3). В Анабарском разрезе была установлена последовательность аммонитовых зон верхнего келловея - низов среднего оксфорда и частично верхнего оксфорда (Amoeboceras (Prionodoceras) spp.). Стратиграфический объем сиговской свиты севера Западной Сибири и севера Средней Сибири существенно отличался [Решения..., 1969; 1981] (рис. 3). Реперный уровень с глауконитовыми песками и фосфатными конкрециями, ранее относимый к волжским образованиям [Сакс и др., 1963; Духанин, 1976а], стал надежно увязываться с нижним кимериджем, благодаря находкам Rasenia spp. [Стратиграфия..., 1976; Решения..., 1981]. Тем не менее, его не включили в состав сиговской свиты, а рассматривали как самостоятельное подразделение, трансгрессивно со стратиграфическим перерывом залегающее на песках низов верхнего оксфорда.

В вышележащих глинах были найдены аммониты средневолжского подъяруса Taimyrosphinctes (? Dorsoplanites) sp. [Стратиграфия..., 1976; Месежников, 1984], однако этот уровень так же рассматривался как самостоятельная толща и не включался в синхронную глинистую буолкалалахскую свиту (рис. 3). Последняя в объеме волжского яруса и берриаса был выделен на р. Буолкалах [Решения..., 1981; Гольберт и др., 1983] и прослежен на правых притоках р. Анабар. Предполагалось, что, собственно, на р. Анабар буолкалахская свита присутствует в значительно ограниченном стратиграфическом объеме (верхняя часть бореального берриаса) и трансгрессивно, с перерывом залегает на волжских образованиях [Стратиграфия..., 1976; Опорный разрез..., 1981; Решения..., 1981]. Дальнейшие биостратиграфические исследования позволили наметить в Анабарском разрезе аммонитовые зоны верхов среднего [Никитенко и др., 2011] и нижней части верхнего оксфорда [Месежников и др., 1989] (рис. 3). 
В последующем, новые данные, главным образом, микропалеонтологические, позволяли совершенствовать эту стратиграфическую модель [Никитенко, 2009]. Так, волжские глины были включены в состав буолкалахской свиты. Маркирующий пласт глауконитовых песков с фосфатными конкрециями вошел в сиговскую свиту (рис. 3). Таким образом, стратиграфический объем западносибирской сиговской свиты примерно уровнялся с таковым на севере Средней Сибири [Никитенко, 2009].

Анализ литостратиграфической конструкции синхронных разрезов верхней юры и мела севера Западной и Средней Сибири, выявил существенные различия в строении, конструкции и стратиграфическом объеме этих толщ, обусловленные разной историей бассейнов и разными источниками сноса. Это показало, что необходимо разработать полностью самостоятельную стратиграфическую основу для севера Средней Сибири и выделить новые свиты [Никитенко и др., 2013]. Так, вместо западносибирской сиговской свиты для прибрежно- и мелководно-морских разрезов верхов келловея и кимериджа в Анабарском районе была предложена содиемыхаинская свита (рис. 3), со стратотипическими разрезами на правом берегу р. Анабар, в районе р. Содиемыха (рис. 1, 2). Стратиграфические исследования позволили обосновать полный стратиграфический объем буолкалахской свиты (волжский ярус - бореальный берриас). Тем не менее, между юрюнгтумусской и содиемыхаинской свитами, по данным исследования аммонитов, попрежнему, предполагался крупный стратиграфический перерыв в объеме верхов бата низов верхнего келловея [Никитенко и др., 2013].

В 2013 г. на Анабарских разрезах (рис. 1, 2) проведены детальные комплексные исследования стратиграфии, седиментологии, органической геохимии и литогеохимии. Эти работы позволили выявить в низах содиемыхаинской свиты ярко выраженный комплекс аммонитов нижнего келловея с Cadochamoussetia spp., Cadoceras cf. simulans (верхняя часть зоны Cadoceras elatmae и зона Cadochamoussetia tschernyschewi). Несколько выше выявлены Quenstedtoceras nikitinianum и Quenstedtoceras sp., которые могут относится как к самым верхам келловея, так и основанию оксфорда [Стратиграфия..., 1976; Меледина, 1977; Князев и др., 2017] (рис. 4). Таким образом, на современном материале подтверждены полученные ранее [Павлов, 1914; Духанин, 1976а] доказательства присутствия нижнего келловея в Анабарском разрезе.

Существенная разница в ранее полученных биостратиграфических результатах по аммонитам связана с незначительной мощностью стратонов верхов средней юры - низов мела на р. Анабар, линзообразным распределением фоссилий на разных стратиграфических уровнях и участках естественных выходов, протянувшихся на более чем на 25 км от р. Средняя до р. Содиемыха (рис. 1). Так же, ранее, при стратиграфических исследованиях превалировало мнение, о том, что отсутствие находок аммонитов, как ортостратиграфической группы фоссилий, означает и отсутствие соответствующих отложений, что отражено в предыдущих стратиграфических схемах юры и мела, как Западной, так и Средней Сибири [Решения..., 1969; 1981]. Подобная парадигма при стратиграфических построениях продолжает применяться некоторыми специалистами по аммонитам и в настоящее время [Вержбовский, Рогов, 2013; Рогов, 2019; Князев и др., 2017; 2020]. 


\section{БИОСТРАТИГРАФИЯ}

Микрофауна. Фораминиферы и стратиграфия верхов средней юры и низов мела р. Анабар изучались А.А. Герке, В.А. Басовым, Н.В. Шаровской, З.В. Лутовой, С.П. Булынниковой, Б.Л. Никитенко [Сакс и др., 1963; Шаровская, 1966; Лутова, 1976, 1981; Стратиграфия..., 1976; Решения..., 1981; Опорный разрез..., 1981; Никитенко, 2009; Никитенко и др., 2013]. Синтез этих данных позволил предложить дробное расчленение Анабарского разреза и проследить ряд стандартных для Сибири зон по фораминиферам: в верхах юрюнгтумусской свиты слои с Trochammina aff.praesquamata JF22 (= jakovlevae JF22) (верхи верхнего байоса - низы верхнего бата); в содиемыхаинской свите фораминиферовые зоны Conorboides taimyrensis JF32 (верхи верхнего келловея), Trochammina oxfordiana JF36 (нижний и средний оксфорд), Haplophragmoides canuiformis JF40 (верхи оксфорда и низы кимериджа); в буолкалахской свите фораминиферовые зоны Spiroplectammina vicinalis, Dorothia tortuosa JF45 (верхи нижневолжского - нижняя половина средневолжского подъярусов), Ammodiscus veteranus, Evolutinella emeljanzevi JF52 (верхи средневолжского подъяруса - основание бореального берриаса) [Никитенко, 2009; Никитенко и др., 2013].

Новые полевые и микропалеонтологические исследования позволили уточнить фораминиферовую зонацию этого разреза. Верхи юрюнгтумусской свиты, в разрезе А9 (рис. 4) содержат редкие, часто фрагментарные остатки Ammodiscus cf.arangastachiensis, Recurvoides cf.anabarensis, Saccammina compacta, Trochammina cf.jakovlevae [Никитенко, 2009]. В основании содиемыхаинской свиты (сл. 5) выявлен сходный комплекс, но гораздо лучшей сохранности, с Ammodiscus arangastachiensis, A. uglicus, Glomospira ex gr.gordialis, Trochammina jakovlevae и Recurvoides anabarensis, характерный для зоны Trochammina jakovlevae JF22. Несколько выше в зеленовато-серых песках с железистыми оолитами низов сл. 6 (рис. 4) определены редкие Ammodiscus uglicus, Trochammina cf.rostovzevi типичные для фораминиферовой зоны Dorothia insperata, Trochammina rostovzevi JF25. Примерно с этого же уровня или несколько выше 3.В. Лутовой [1976] найдены более разнообразные ассоциации с Conorboides taimyrensis, Geinitzinita crassata, Lenticulina memorabilissima, Astacolus nobilissimus, Lagena borealis, которые можно рассматривать как свидетельство присутствия нерасчлененных зон Ammobaculites igrimensis JF31/Conorboides taimyrensis JF32 (верхи среднего - верхний келловей). Ранее отсюда же с разрезов, расположенных от устья р. Содиемыха до обнажения OK/S2, определялись аммониты Cadoceras cf. stenolobum, Longaeviceras spp., Eboraciceras spp. [Бодылевский, 1960; Сакс и др., 1963; Стратиграфия..., 1976], характеризующие средний - верхний келловей. Подобный фораминиферовый комплекс с Lenticulina ex gr.solita, Glomospirella semiaffixa, Ammodiscus uglicus, Conorboides cf.taimyrensis, Trochammina rostovzevi, Hyperammina sp., Reophax sp. был определен в обнажении OK/S2 в нижней части слоя За (рис. 4) между горизонтами конкреций, с аммонитами нерасчлененных зон Cadoceras elatmae/Cadochamoussetia tschernyschewi нижнего келловея и аммонитами верхов келловея/основания оксфорда [Князев и др., 2017].

В средней (оксфордской) части содиемыхаинской свиты распределение микрофауны крайне неравномерно, как по количественной представительности, так и по 
таксономическому разнообразию. В обнажении А9, нижние 6 м слоя 7 охарактеризованы Glomospirella semiaffixa, Glomospira oxfordiana, Trochammina cf.oxfordiana, Ammobaculites syndascoensis, Eomarsonella cf.paraconica. Гораздо более таксономически обедненные комплексы выявлены в разрезе OK/S2 (слой 3b/низы слоя 4): Ammodiscus cf.thomsi, Trochammina cf.oxfordiana, Epistomina sp., Hyperammina sp., Glomospirella semiaffixa (рис. 4). Эти комплексы характерны для зоны Trochammina oxfordiana JF36 (нижний - основание верхнего оксфорда). Ранее в разрезах между обнажениями A9 и OK/S2 над уровнем c комплексом зоны JF36, в прикровельной части содиемыхаинской свиты, отмечались находки Recurvoides disputabilis, Ammodiscus thomsi, Glomospira oxfordiana и др. [Никитенко, 2009; Никитенко и др., 2013], которые могут рассматриваться в составе зоны Recurvoides disputabilis JF37.

В глауконитовом базальном пласте буолкалахской свиты, мощностью $0.3-0.8$ м, выдержанном в обнажениях на расстоянии более 25 км, определены остатки микрофауны верхов оксфорда - кимериджа. В обнажении А9 (рис. 4) в слое 8 найдены Recurvoides sublustris, Trochammina taboryensis, Haplophragmoides canuiformis, Pseudolamarckina cf.lopsiensis и зубы рыб. Фораминиферовые комплексы типичны для нерасчлененных зон Haplophragmoides canuiformis JF40/Pseudolamarckina lopsiensis JF41. В разрезе OK/S2 (слой 6) определены Ammodiscus cf.thomsi, Recurvoides cf.sublustris, Trochammina cf.kumaensis, Glomospirella intrita, характерные для зоны Haplophragmoides canuiformis JF40 (верхи верхнего оксфорда - низы нижнего кимериджа. Несколько выше по течернию р. Анабар, в этом же пласте выявлены: Ammodiscus thomsi, Evolutinella nana, Haplopragmoides canuiformis, Epistomina sp., Pseudolamarckina cf.lopsiensis, относящиеся к фораминиферовой зоне Pseudolamarckina lopsiensis JF41 (верхи нижнего - верхний кимеридж).

Вышележащая часть низов буолкалахской свиты охарактеризована микропалеонтологическими данными по разрезу А9 (рис. 4). Таксономическое разнообразие фораминифер последовательно нарастает вверх по разрезу. В основании глинистой части разреза (основание слоя 10) определены Ammodiscus zaspelovae, Verneuilinoides postgraciosus, Recurvoides stschekuriensis, Trochammina ex gr.kumaensis, Glomospirella intrita зоны Kutsevella haplophragmoides JF44 (низы нижневолжского подъяруса) и зубы рыб. В интервале 0.5 - 1 м от основания слоя 10 (рис. 4) выявлены фораминиферовые комплексы (Dorothia tortuosa, Glomospirella intrita, Evolutinella emeljanzevi, Recurvoides praeobskiensis, Cribrostomoides mirandus, Trochammina sp.) верхов зоны Spiroplectammina vicinalis, Dorothia tortuosa JF45, которая соответствует верхней части средневолжского подъяруса. Несколько выше найдены Evolutinella emeljanzevi (многочисленные), Recurvoides praeobskiensis, Trochammina rosacea, Gaudryina ex gr.gerkei, Glomospirella intrita, Cribrostomoides sp., характерные для зоны Ammodiscus veteranus, Evolutinella emeljanzevi JF52 (верхи средневолжского подъяруса - основание бореального берриаса). В вышележащей части разреза (рис. 4) (слой 10, 3 - 8 м от основания) в комплексах начинают стабильно встречаться известковистые фораминиферы: Lenticulina pseudoarctica, L. sossipatrovae, Marginulina robusta, но количественно преобладают агглютинирующие формы: Evolutinella emeljanzevi, Ammodiscus micrus, Cribrostomoides mutabilis, C. volubilis, Recurvoides obskiensis, Ammobaculites gerkei, Gaudryina gerkei, 
Hyperammina sp., Trochammina rosaceaformis, Ammobaculites gerkei, Kutsevella praegoodlanlangensis, Saccammina sp. Подобные ассоциации типичны для фораминиферовой зоны Gaudryina gerkei, Trochammina rosaceaformis KF1 (середина бореального берриаса).

Микрофитопланктон. Комплексы микрофитопланктона в разрезе на р. Анабар представлены обильными и разнообразными диноцистами, которые в основном принадлежат к семейству Gonyaulacaceae. Состав, количественное соотношение таксонов и их распределение по разрезу приведено на рисунке (рис. 5). Значительного количества также достигают празинофиты Leiosphaeridia. В нижней части разреза (верхний бат середина волжского яруса) их количество колеблется от $9 \%$ до $20 \%$, в верхней части они становятся доминантами (44-65\%). Празинофиты родов Cymatiosphaera, Tasmanites, Pterospermella и актитархи (Micrhystridium, Veryhahium, Lophosphaeridia) малочисленны (0,4-2\%) и чаще встречаются в келловее, оксфорде и нижнем кимеридже. В берриасе большая часть образцов содержала незначительное количество микрофитопланктона, поэтому установить комплексы и определить количественное соотношение таксонов в них в этой части разреза не удалось. Таким образом, последовательность диноцист в полном объеме изучена в батско-волжском интервале. Основные характеристики выделенных биостратонов по диноцистам приведены в таблице (табл. 1).

В результате палинологического изучения Анабарского разреза впервые на территории Сибири установлена зона по диноцистам в верхней части бата. Ранее в этом регионе были обнаружены только единичные находки батских диноцист в Сургутском и Шаимском районах Западной Сибири [Шурыгин и др., 2000]. Появление в Анабарском разрезе Sirmiodinium grossii Alberti в верхней части бата и Meiourogonyaulax planoseptata Riding в низах келловея позволяют опознавать на территории Сибири зону Sirmiodinium grossii, которая была впервые описана для этого интервала в Баренцевоморском регионе (рис. 5; табл. 1). Стратиграфическое положение зоны в исследованном разрезе дополнительно обосновано таксонами, которые широко распространены в верхней части бата в бореальных и арктических областях северного полушария (рис. 5). Таким образом, зона Sirmiodinium grossii рассматривается как биостратиграфическая зона комплексного обоснования. Следует отметить, что точное положение ее нижней границы не до конца ясно. В первоописании отсутствует калибровка с аммонитовыми зонами, а в разрезе на р. Анабар нижняя граница не прослежена. Анализ палинологической литературы показывает, что уровень появления ключевых таксонов и/или их акме прослеживается в пределах средней части бата: аммонитовые зоны (а-зоны) progracilis-hodsoni Североморского региона и izhmae-variabile Баренцевоморского региона и Русской плиты (табл. 1). В разрезе на р. Анабар, вероятно, представлена верхняя часть зоны Sirmiodinium grossii, поскольку комплекс диноцист содержит виды Trichodinium scarburghense (Sarjeant) Williams et al., Stephanelytron scarburghense Sarjeant, Apteodinium bucculiatum Davies, которые характерны для низов келловея и переходных бат-келловейских слоев на севере Западной Европы и Канады (табл. 1).

Зона Fromea tornatilis выявлена в разрезе на р. Анабар в средней части нижнего келловея по представительному присутствию вида-индекса (рис. 5). Впервые она была 
описана в разрезах на Русской плите, со стратотипом на р. Пижма [Riding et al., 1999]. Повышенное количество Fromea tornatilis (Drugg) Lentin et Williams было прослежено и в нижнем келловее Западной Сибири, что позволило установить там эту зону [Шурыгин и др., 2000; Ilyina et al., 2005]. Материалы по скв. Тюменская сверхглубокая 6 (СГ6) показывают, что F. tornatilis появляется в значительном количестве в самой верхней части фораминиферовой зоны (ф-зоны) JF28 (ранее F14), что соответствует верхам а-зоны elatmae - низам tschernyschewi [llyina et al., 2005; Никитенко и др., 2013]. В разрезе на р. Анабар вид F. tornatilis обнаружен в средней части ф-зоны JF25, что примерно соответствует данному уровню. Здесь же появляются первые представители рода Yalkalpodinium, что характерно для нижнего келловея Австралии [Riding et al., 2010].

Верхняя граница зоны Fromea tornatilis в разрезе на р. Анабар не установлена из-за сокращенной мощности келловея и размыва отложений в его верхней части, что также не позволило изучить комплексы диноцист из верхней части этого яруса. Выше по разрезу, в нижнем оксфорде определены комплексы диноцист, которые содержат стратиграфически важные виды, обеспечивая корреляцию с Восточной и Западной Европой, Баренцевоморским шельфом и Арктической Канадой (табл. 1). За исключением последней области, здесь установлена зона Wanaea fimbriata, нижняя граница которой уверенно прослеживается в основании нижнего оксфорда по появлению вида-индекса. На р. Анабар эта зона охарактеризована рядом дополнительных признаков, которые хорошо опознается в одновозрастных разрезах различных бореальных областей (табл. 1). В разрезе изучена, по-видимому, верхняя часть зоны, поскольку низы оксфорда не опробованы (рис. 5). Стратиграфическое положение кровли зоны в самых верхах нижнего оксфорда подтверждается в разрезе на р. Анабар данными по аммонитам.

В верхней части среднего оксфорда в разрезе на р. Анабар установлены слои с Cribroperidinium granuligerum по появлению и постоянному присутствию вида-индекса (табл. 1). На севере Западной Европы постоянные находки и/или увеличение количества этого вида отмечается с середины среднего оксфорда (основание а-зоны tenuiserratum) [Powel, 1992]. Верхняя часть слоев с Cribroperidinium granuligerum в разрезе на р. Анабар, возможно, захватывает низы верхнего оксфорда, так как здесь появляется Paragonyaulacysta? borealis (Brideaux et Fisher) Stover et Evitt. Для Сибири наиболее древние находки этого вида характерны для верхнего оксфорда (слои с аммонитами Amoeboceras) [Шурыгин и др., 2000]. Однако следует отметить, что в других бореальных районах (Гренландия, Баренцевоморский шельф) он рассматривается как характерный компонент комплексов диноцист, начиная с верхнего келловея [Smelror, 1993].

В самых верхах оксфорда и нижней части кимериджа в разрезе на р. Анабар по присутствию характерных таксонов хорошо опознаются слои с Heslertonia? pellucida, Senoniasphaera jurassica (рис. 5; табл. 1). Ранее по материалам из разреза Нордвик, который принят как опорный для бореальных районов, их стратиграфический объем рассматривался в пределах верхней части верхнего оксфорда, а в нижней части кимериджа были установлены слои с Scriniodinium granulatum, Corculodinium inaffectum по появлению первого вида-индекса [Никитенко и др., 2015а]. Изучение разреза на р. Анабар показало, что S. granulatum появляется в Сибири ниже, в нижнем оксфорде (рис. 5). 
Однако появление второго вида-индекса отмечается в Анабарском разрезе на том же уровне, что и на п-ве Нордвик, в средней части нижнего кимериджа. Таким образом, новые материалы позволяют расширить стратиграфический диапазон слоев с Heslertonia ? pellucida, Senoniasphaera jurassica за счет включения в их объем нижней части нижнего кимериджа. В средней части кимериджа устанавливаются слои с Corculodinium inaffectum (табл. 1). Вид-индекс имеет важное стратиграфическое и корреляционное значение, так как его появление в средней части кимериджа выявлено также в Западной Европе, в Польше и на севере Урала (табл. 1).

Слои с Cribroperidinium? edwardsii, Trichodinium erinaceoides, установленные в разрезе Нордвик в верхней части кимериджа и нижней части нижневолжского подъяруса [Никитенко и др., 2015а], опознаются в разрезе на р. Анабар по дополнительному признаку, увеличению количества Paragonyaulacysta? borealis (Нордвик: 7-14\% при среднем 1,5-3\%; Анабар: 5\% при среднем 0,5-1\%).

В верхней части средневолжского подъяруса и низах верхневолжского в разрезе на р. Анабар установлены слои с Achomosphaera neptuni, Bourkidinium (рис. 5; табл. 1). Ряд признаков хорошо прослеживается на севере Сибири по материалам разрезов Нордвик (данные Е.Б. Пещевицкой) и Оленек [Nikitenko et al., 2018]. Благодаря появлению стратиграфически важных видов этот уровень также можно проследить на Русской плите и в Западной Европе (табл. 1).

В нижней части верхневолжского подъяруса в разрезе на р. Анабар появляется вид Gochteodinia villosa (Vozzhennikova) Norris, который является важным биостратиграфическим репером для бореальных районов (табл. 1). На территории Сибири это биособытие прослеживается изохронно в низах верхневолжского подъяруса в разрезах Нордвик (данные Е.Б. Пещевицкой) и Оленек [Nikitenko et al., 2018], в то время как на Русской плите и севере Западной Европы наблюдается ниже, в верхней части средневолжского подъяруса и середине портланда (табл. 1). Возрастная разница в появлении этого вида может быть связана с высокоширотным местонахождением и палеогеографическим особенностями комплексов диноцист. Отличительные признаки верхней границы слоев с G. villosa (появление Cassiculosphaeridia reticulata Davey, Batioladinium varigranosum (Duxbury) Davey, Occisucysta tentorium Duxbury в верхней части верхневолжского подъяруса) в разрезе на р. Анабар не установлены. Вероятно, это является результатом небольшого количества диноцист в переходном волжскоберриасском интервале: в комплексах микрофитопланктона здесь доминируют празинофиты (до 65\%). Однако вид C. reticulata присутствует в нижней части берриаса. В средней части этого яруса количество микрофитопланктона сокращается, что не позволяет изучить комплексы диноцист в полном объеме и определить процентное соотношение таксонов.

Наземные палиноморфы. На основе изучения биостратиграфической последовательности спор и пыльцы наземных растений в изученном разрезе установлено девять биостратонов в ранге зон и слоев с палинофлорой. Особенности споровопыльцевых комплексов показаны на рис. 6 Обоснование границ биостратонов и палинологические признаки, важные для стратиграфии, приведены на табл. 2. 
В нижней части разреза, в бате и келловее, прослежены палинозоны, которые были установлены В.И. Ильиной на севере Сибири (побережье Анабарской губы, о. Бегичев) в разрезах, хорошо охарактеризованных фауной, и, в дальнейшем, прослежены во многих районах Западной Сибири [Ильина, 1985; Шурыгин и др., 2000; Никитенко и др., 2013]. Выше, в среднем и верхнем келловее и нижней части оксфорда (до основания аммонитовой зоны С. gloriosum) В.И. Ильина выделяла слои с Piceapollenites, Cyathidites, Gleicheniidites, Sciadopityspollenites macroverrucosus, Classopollis (JSP12). В качестве главных отличий от спорово-пыльцевого комплекса подстилающих отложений рассматривалось увеличение количества мешковой пыльцы голосеменных (также наблюдается и в изученном разрезе), резкое сокращение разнообразия спор папоротников и исчезновение морфотипов, определяемых советскими палинологами как Microlepidites sp. и Hemitelia parva (Dor.) Timosh. Зарубежные палинологи относят эти формы к роду Dictyophyllidites, который широко распространен в верхней юре и нижнем мелу, в том числе и вид D. equiexinus (Coup.) Dett., который по морфологическим особенностям сходен с H. parva [Norris, 1969, 1973; Dorhofer, 1977; и др.]. В изученном разрезе род Dictyophyllidites присутствует постоянно, и обеднения спорово-пыльцевого комплекса в нижнем оксфорде не наблюдается. Анализ нового материала и литературных данных показывает, что важным признаком для этого интервала может являться регулярное присутсвие Gleicheniidites spp. и G. senonicus Ross (табл.2). Отметим, что В.И. Ильина также рассматривала этот род как один из важных признаков спорово-пыльцевого комплекса среднего келловея - нижнего оксфорда и включила его в название биостратона в качестве таксона-индекса [Ильина, 1985; Шурыгин и др., 2000]. Постепенное увеличение роли глейхениевых в келловее-оксфорде отмечалось и другими палинологами, что особенно характерно для западных районов Западной Сибири [Стратиграфо-палеонтологическая..., 1972; Пуртова, Игнатова 1987; и др.].

В верхней части разреза выявлены слои с палинофлорой, которые ранее были установлены автором в разрезах Нордвик и Оленек (рис. 6, табл.2). Основания некоторых палиностратонов (в верхнем оксфорде, средне- и верхневолжском подъярусах) могут рассматриваться как важные биостратиграфические реперы, имеющие значительный корреляционный потенциал. Палинологические признаки, положенные в основу выделения этих границ, прослеживаются не только в Сибири, но также в Западной Европе и ряде других регионов (табл.2).

Отметим, что ранее палиностратоны в верхних частях оксфорда и волжского яруса выделялись, в основном, на основе количественных характеристик таксонов широкого стратиграфического диапазона (Piceapollenites, Podocarpidites, Pinuspollenites, Classopollis, Vitreisporites pallidus (Reissinger) Nilsson, Klukisporites variegatus Couper, Densoisporites velatus Weyland et Kreiger, Gleicheniidites - см. табл.2), которые часто зависят от фаций [Глушко, 1980; Шейко, 1980; Пещевицкая, 2010; и др.]. Эти палиностратоны имели ограниченное географическое распространение, так как были прослежены только в одном из разрезов: на п-ве Нордвик или западном берегу Анабарской губы [Ильина, 1985; Шурыгин и др., 2000; Никитенко и др., 2013]. 
Уровни появления стратиграфически важных таксонов верхневолжского подъяруса (Selaginela utriculosa Krasn., Cicatricosisporites) сейчас пересмотрены на основе новых материалов и анализа литературы и прослежены в более низких стратиграфических горизонтах (рис. 6; табл. 2). Эта последовательность палиностратонов также имела значительные стратиграфические перерывы: в среднем оксфорде и кимеридже - нижней части волжского подъяруса. Биостратиграфический анализ нового палинологического материала из разреза на р. Анабар, а также разрезов Нордвик и р. Оленек позволил установить в интервале с верхнего оксфорда по берриас непрерывную последовательность спорово-пыльцевых биостратонов с четким обоснованием границ, обладающих корреляционным потенциалом.

\section{ЛИТОСТРАТИГРАФИЯ, ПЕТРОГРАФИЧЕСКИЕ И ЛИТОГЕОХИМИЧЕСКИЕ ОСОБЕННОСТИ ПОРОД}

В стратиграфическом разрезе долины р. Анабар снизу вверх изучены юрюнгтумусская, содиемыхаинская, буолкалахская свиты (рис. 2, 4). Верхняя часть юрюнгтумусской свиты (в объеме верхов среднего - низов верхнего бата) сложена прибрежно-морскими, приливно-отливными и субконтинентальными песками тонко- и мелкозернистыми, светло-серыми, желтоватыми, косо- и линзовиднослоистыми, с протяженными тонкими линзами угля, прослойками буроватых песчаных алевритов, линзами и рассеянной галькой изверженных пород, скоплениями углефицированного растительного детрита. Встречаются уровни с крупными эллипсоидальными (1 х 3 м) конкрециями известковистого песчаника серого, часто содержащие крупные обломки минерализированной древесины, по простиранию слоя периодически встречаются обильные скопления разноориентированных стволов деревьев. В прикровельной части разреза на отдельных участках в песчаных конкрециях отмечаются включения брекчий массивных голубовато-серых известковистых аргиллитов. В толще встречаются остатки аммонитов Acticoceras ishmae [Стратиграфия..., 1876; Князев и др., 2017], редкие обломки ростров белемнитов, призматический раковинный слой и обломки раковин двустворок, комплексы фораминифер зоны Trochammina jakovlevae JF22 и горизонтальные следы жизнедеятельности (рис. 4). По составу пески верхов юрюнгтумусской свиты относятся к граувакково-аркозово-кварцевому типу [Осадочные..., 1987] или кварцевым грауваккам [Шутов, 1967]. Обломки пород представлены преимущественно эффузивами кислого и среднего составов, частью хлоритизированных, присутствуют кремнистые и глинистые породы, редко известняки. Слюды (в среднем 2-5\%), представлены биотитом, в меньшей степени мусковитом. Среди акцессориев преобладают циркон, минералы эпидотцоизитовой группы, сфен, реже встречаются роговая обманка, гранат, апатит. Присутствуют пиритизированные и гелифицированные растительные остатки. Цемент глинистый и карбонатный.

Юрюнгтумусская свита трансгрессивно перекрывается алеврито-песчаными образованиями содиемыхаинской свиты (верхи бата - нижняя часть верхнего оксфорда). При первом описании свиты [Никитенко и др., 2013] в ее наименовании были допущены опечатки. В данной работе приводится исправленное название - содиемыхаинская свита, по р. Содиемыха, правому притоку р. Анабар (рис. 2, 4, 7). Свита сложена прибрежно- 
морскими и мелководно-морскими алевритами песчаными, крупнозернистыми и песками мелкозернистыми алевритистыми, буровато-желтыми и буровато-серыми массивными или пологокосослоистыми, иногда с линзовидным чередованием алевритов, глин алевритистых и песков, с редкой хорошо окатанной галькой и гравием изверженных пород, сидеритовыми стяжениями (рис. 2, 4).

Особенностью свиты является наличие слабо сортированных глинисто-алевритопесчаных прослоев, обогащенных железосодержащими компонентами (сидеритовые конкреции, гетит-шамозитовые оолиты и бобовины), особенно многочисленными в нижней части разреза. На разных уровнях в выходах выше устья р. Содиемыха (обн. OK/S2) отмечаются протяженные горизонты линзовидных, субсферических или эллипсоидальных конкреций известковистого песчаника и алевролита, местами со скоплениями раковин аммонитов, реже встречаются раковины двустворок, фрагменты белемнитов, обломки древесины. В нижней половине свиты отмечаются внутриформационные размывы, выраженные в эрозионных поверхностях. Мощность содиемыхаинской свиты в стратотипических разрезах составляет 9 - 11 м, возрастая в северном направлении до 65 м и сокращаясь до полного выклинивания в южном направлении.

По своему составу песчаные образования относятся преимущественно к кварцевоаркозово-граувакковому типу [Осадочные..., 1987] или полевошпатовым грауваккам [Шутов, 1967]. Доля обломков пород возрастает в железосодержащих прослоях. Состав цемента, обломков пород, слюды и акцессориев близки к таковым из юрюнгтумусской свиты.

Нижняя граница свиты неровная, резкая (рис. 2, 4). Несмотря на это верхи юрюнгумусской и низы содиемыхаинской свит охарактеризованы комплексами разных микрофоссилий, характерными для зон: Trochammina jakovlevae JF22 (фораминиферы), Sirmiodinium grossi (диноцисты) и JSPA10b (наземные палиноморфы), что свидетельствует о незначительном стратиграфическом объеме размыва (рис. 2, 4). В нижней части свиты встречаются аммониты нижнего келловея [Павлов, 1914; Духанин, 1976а; Князев и др., 2017]. Комплексный биостратиграфический анализ этих данных позволяет точно определить стратиграфическое положение нижней границы, как низы верхнего бата.

Проведенные последние стратиграфические исследования в Анабарских разрезах не выявили, предполагавшейся ранее перемытой коры выветривания [Стратиграфия..., 1976] в нижней части свиты между келловеем и оксфордом (слои 6 и 7, обн. А9; слой 2а, обн. OK/S2) (рис. 1, 2, 4). Уточнено стратиграфическое положение верхней границы и объем содиемыхаинской свиты. Ранее в прикровельную часть свиты по гранулометрическому составу включался маркирующий пласт глауконитовых песков с фосфатными желваками и аммонитами нижнего кимериджа [Никитенко и др., 2013]. Однако по генетическим (базальный трансгрессивный пласт), петрографическим и геохимическим особенностям этот пласт гораздо ближе к мелководно-морским образованиям вышележащей буолкалахской свиты, нежели чем к пескам содиемыхаинской (рис. 2, 4, 7). Близ кровли содиемыхаинской свиты ранее были обнаружены верхнеоксфордские аммониты [Павлов, 1914; Князев, 1975; Стратиграфия..., 1976; Месежников и др., 1989] и фораминиферы 
[Никитенко, 2009; Никитенко и др., 2013]. Содиемыхаинская свита на разных стратиграфических уровнях и участках еe развития содержит богатые комплексы аммонитов келловея и оксфорда, микрофоссилий (фораминиферы, диноцисты и наземные палиноморфы) верхов бата - низов верхнего оксфорда [Никитенко и др., 2013].

В стратотипических разрезах на р. Буолкалах (междуречье рр. Анабар - Оленек) [Опорный разрез..., 1981; Решения..., 1981; Гольберт и др., 1983] и на р. Оленек [Nikitenko et al., 2018] волжские глины буолкалахской свиты с крупным стратиграфическим перерывом залегают на среднеюрских толщах. Таким образом, полный стратиграфический объем свиты оставался неясным. Ранее в базальных конгломератах буолкалахской свиты в разрезе на р. Оленек был встречен смешанный кимериджско нижневолжский комплекс диноцист [Nikitenko et al., 2018].

Базальные слои буолкалахской свиты в изученных разрезах сложены прибрежно- и мелководно-морскими песками, алевритистыми, глауконитовыми, с большим количеством темно-серых, буроватых фосфатно-известковистых конкреций разнообразной формы, с остатками ростров белемнитов, многочисленными обломками древесины. Выше залегает выдержанный по протиранию горизонт протяженных линзовидных конкреций известковистого алевролита песчаного и песчаника темносерого, слегка зеленоватого с поверхности буроватого, обогащенного глауконитшамозитовыми бобовинами и оолитами, а также фосфатизированными обломками, фрагментами ростров белемнитов $и$ древесины. Местами пласт интенсивно биотурбирован, с крупными вертикальными следами жизнедеятельности (рис. 2, 4). По особенностям строения базальные слои объединяются в пачку 1, мощностью от 0.3 - 1м, до 5 м на притоках р. Анабар [Стратиграфия..., 1976; Решения..., 1981]. Нижняя граница свиты и пачки неровная, резкая, в основании часто встречается гравий и мелкая галька.

В базальных слоях (обн. А9, слой 8; обн. OK/S2, слой 6) буолкалахской свиты установлены нерасчлененные комплексы фораминифер верхов оксфорда - кимериджа (зоны JF40/JF41), комплекс верхов оксфорда - низов кимериджа (зона JF40) и комплекс верхов нижнего - верхнего кимериджа (зона JF42). Там же определены два комплекса диноцист: в основании свиты - комплекс верхов оксфорда - низов кимериджа и несколько выше - средней части кимерджа (рис. 2, 4). Ранее с этого уровня приводились находки нижнекимериджских аммонитов Rasenia spp. [Стратиграфия..., 1976; Месежников, 1984]. Несколько выше в пачке 1 (обн. А9, слой 9; обн. OK/S2, слой 7) выявлены комплексы фораминифер низов нижневолжского подъяруса (зона JF44), комплексы диноцист верхов кимериджа - низов нижневолжского подъяруса и наземных палиноморф нижне- средневолжского подъяруса (рис. 2, 4).

Вышележащая часть изученного разреза нижней подсвиты [Nikitenko et al., 2018] буолкалахской свиты (обн. А9, пачка 2, слой 10), видимой мощностью около 14 м, сложена пакетами равномерного чередования глин тонкоотмученных до алевритовых темносерых, с буроватым оттенком с линзами и прослоями алеврита глинистого буроватого, с редкими глинисто-известковистыми конкрециями (рис. 2, 4, 7). Алевритовые обломки в значительной степени мелкозернистые и представлены преимущественно кварцем и полевыми шпатами. В толще повсеместно встречается слюда (5-10\%), представленная 
биотитом, реже мусковитом. Присутствует мелкий растительный детрит, замещенный различными минералами железа (преимущественно пиритом). Среди акцессорных примесей резко преобладает циркон, встречаются минералы эпидот-цоизитовой группы, сфен. На разных уровнях найдены многочисленные остатки аммонитов, обломки углефицированной древесины. Определены остатки средневолжских аммонитов Taimyrosphinctes (? Dorsoplanites) sp. [Стратиграфия..., 1976; Месежников, 1984]. Комплексы фораминифер, диноцист и наземных палиноморф характеризуют соответствующие биостратоны средневолжского подъяруса - низов бореального берриаса (рис. 4, 7).

Таким образом, детальные комплексные стратиграфические исследования низов буолкалахской свиты разрезов на р. Анабар позволили существенно уточнить стратиграфическое положение нижней границы свиты, как самые верхи оксфорда основание кимериджа и соответственно стратиграфический объем всей свиты как верхи оксфорда - бореальный берриас (рис. 4, 7). В такой интерпретации разреза базальный горизонт буолкалахской свиты фиксирует новый крупный этап осадконакопления, прослеживаемый как нижняя граница литостратонов разного уровня по всему Арктическому и частично Бореальному регионам [Шурыгин и др., 2000; Решение..., 2004; Никитенко, 2009; Никитенко и др., 2013].

Анализ особенностей химического состава толщ верхов средней юры - низов мела в районе исследований выполнен впервые. Литогеохимическая характеристика ряда эталонных юрских разрезов севера Средней Сибири, в том числе на р. Анабар, представлены в работе М.А. Левчука [1985], однако, в целом, рассматриваемый в настоящей работе стратиграфический интервал Анабарского разреза не был охарактеризован.

Среди породобразующих компонентов минимальными содержаниями $\mathrm{TiO}_{2}, \mathrm{Al}_{2} \mathrm{O}_{3}$, $\mathrm{Fe}_{2} \mathrm{O}_{3}$ и $\mathrm{MgO}$ отличается юрюнгтумусская свита. Содержание кальция максимально в базальных слоях содиемыхаинской свиты, серы в железистых прослоях, а $\mathrm{SiO}_{2}$ в основном разрезе свиты. Показательно высокое содержание $\mathrm{Na}_{2} \mathrm{O}$ в слоях морской буолкалахской свиты (табл. 3).

Относительно содержаний элементов-примесей (ЭП), включая редкоземельные элементы (РЗЭ), для буолкалахской свиты примечательно то, что большинство ЭП и часть P3Э (La, Pr, Nd, Sm, Gd) имеют отчетливую тенденцию к снижению своих значений вверх по разрезу (за исключением Ва и Th), начиная с максимальных значений в базальных глауконитовых слоях, отличающихся высоким содержанием железа и заканчивая минимальными для свиты значениями ЭП (табл. 3). По сравнению с подстилающими породами, в этой свите повышены содержания Сu, Zn, Rb, U, понижены - Zr, Hf. В целом, исключая базальные слои свит и железистые прослои разреза, существенно глинистая буолкалахская свита характеризуется высокими содержаниями большинства элементовпримесей.

Повышенными и максимальными значениями сорбированных V, Cr, Co, Ni, Cu, Zn, $\mathrm{Nb}$, Th и большинства РЗЭ характеризуются железистые прослои содиемыхаинской свиты, в отличие от минимальных и низких в основном ее разрезе (за исключением бария). 
Юрюнгтумусская свита резко отличается от всего разреза низкими содержаниями $\mathrm{V}, \mathrm{Co}, \mathrm{Ni}$, $\mathrm{Zn}$, среди редкоземельных элементов - Sc, Y, Ce, Cd (табл. 3).

Спектрометрические исследования разреза верхов бата - низов берриаса, позволили определить распределения значений ${ }^{40} \mathrm{~K}$ (БК/кг) (рис. 4). Вариации содержания

${ }^{40} \mathrm{~K}$ связаны с динамикой сноса осадочного материала и близостью источников сноса. Наиболее интенсивное накопление осадков происходило во время формирования субконтинентальных и прибрежных толщ юрюнгтумусской свиты (середина бата). В конце бата - оксфорде установился прибрежно-морской, мелководно-морской режим осадконакопления и процессы размыва осадков преобладали над сносом осадочного материала, что отражено в снижении значений ${ }^{40} \mathrm{~K}$. В верхах оксфорда - кимеридже и волжском ярусе содержание ${ }^{40} \mathrm{~K}$ возрастает, режим осадконакопления сменяется к стабильно мелководно-морскому, усиливаются и процессы сноса, и накопления осадков.

\section{ОРГАНИЧЕСКАЯ ГЕОХИМИЯ}

Концентрации содержания $\mathrm{C}_{\text {орг }}$ в исследованных образцах укладываются в узкий диапазон: 0,20 - 0,94 \% на породу (в среднем 0,49 \%) и 0,53 - 0,78 \% на породу (в среднем 0,34 \%) для разрезов A9 и OK/S2, соответственно. Согласно классификации Н.Б. Вассоевича [Вассоевич, 1972; Справочник..., 1998] такие содержания $\mathrm{C}_{\text {орг }}$ не превышают его кларковых значений (для аргиллитов 0,9\%). Несколько повышенные значения $C_{\text {орг }}$ (> 0,5\%) наблюдаются для проб разреза OK/S2 из верхов юрюнгтумусской и низов содиемыхаинской свит и основания буолкалахской свиты. В разрезе А9 пробы со значениями $\mathrm{C}_{\text {орг }}$ выше среднего (0,51-0,94\%) сгруппированы в верхней, волжскоберриасской, части буолколахской свиты (рис. 4). Верхняя часть содиемыхаинской свиты и пограничные горизонты с буолколахской свитой характеризуются относительно

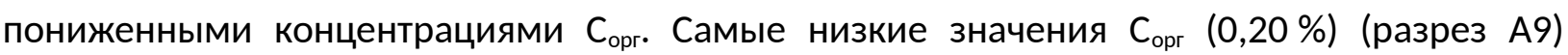
отмечены в двух пробах из нижних, приграничных слоев буолкалахской свиты. Ниже, в

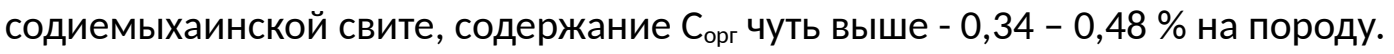

Результаты пиролиза свидетельствуют о низком нефтегазогенерационном потенциале исследованных пород и согласуются с незначительными содержаниями $\mathrm{C}_{\text {орг }}$ [Peters, 1986; Лопатин, Емец, 1987; Peters et al, 2005]. Значения параметра $\mathrm{S}_{1}$, характеризующего выход сорбированных органических соединений, удалось определить в трех пробах из верхов буолкалахской свиты (разрез А9), в которых этот параметр изменяется от 0,02 до 0,03 мгУВ/г породы. Значения $\mathrm{S}_{1}$, измеренные для содиемыхаинской свиты (13 проб) в разрезе OK/S2, также очень низкие (0,01 0,03 мг УВ/г породы). Выход компонентов, высвобождающихся при термодеструкции керогена (пик $\mathrm{S}_{2}$ ), подобно показателю $\mathrm{S}_{1}$, определяется на пределе чувствительности метода: разрез A9 - в среднем 0,15 мг УВ/г породы при разбросе 0,05 - 0,43; разрез OK/S2 - в среднем 0,09 мг УВ/г породы при разбросе 0,05 - 0,14. Относительно повышенные значения параметра $S_{2}$ (0,20 - 0,43 мгУВ/ г породы) характеризуют четыре пробы из верхов буолкалахской свиты разреза А9. Температура максимальной интенсивности выделения углеводородов в пике $\mathrm{S}_{2}\left(\mathrm{~T}_{\max }\right)$, измеренная для этих четырех проб, изменяется от 412 до $434^{\circ} \mathrm{C}$ и соответствует незрелому органическому веществу [Peters et al, 2005]. Для остальных проб $\mathrm{T}_{\max }$ не установлен, т.к. значения пика $\mathrm{S}_{2}$ этих проб меньше 0,2 мг УВ/ 
г породы, что не позволяет определить корректное значение $\mathrm{T}_{\max }$ [Peters, 1986; Лопатин, Емец, 1987; Peters et al, 2005].

Органическое вещество пород исследованных разрезов характеризуется тяжелым изотопным составом углерода (обогащено изотопом ${ }^{13} \mathrm{C}$ ). Для содиемыхаинской и

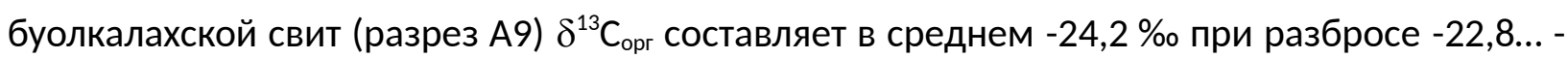
$-25,7 \%$, а для верхов юрюнгтумусской, содиемыхаинской и основания буолкалахской свит (разрез OK/S2) изменяется от $-26,2$ до -23,9 \%о при среднем значении $-24,9$ \%. Для

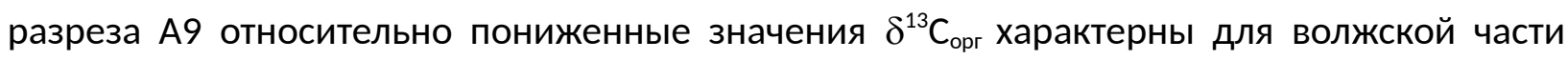
буолкалахской свиты (-25,0... -25,7\%о) (рис. 4), тогда как пробы содиемыхаинской свиты имеют значения $\delta^{13} \mathrm{C}_{\text {орг }} \geq-23,0 \%$. Резкое уменьшение $\delta^{13} \mathrm{C}_{\text {орг }}$ отмечено в нижней приграничной части буолкалахской свиты как для разреза А9 (с -24,9 \%о до -25,7 \%о), так и для разреза OK/S2 (с -24,6\%о до -26,2\%о) (рис.4). Относительно более легкое по изотопному составу (обедненное изотопом ${ }^{13} \mathrm{C}$ ) органическое вещество отмечено в приграничных прослоях юрюнгтумусской и содиемыхаинской свит разреза OK/S2 (-25 ... $-26,2 \%$ ). Снизу вверх по этому разрезу содиемыхаинской свиты изотопный состав углерода показывает тенденцию к обогащению изотопом ${ }^{13} \mathrm{C}$, причем на уровне келловея низов оксфорда (рис. 4) фиксируется "качелеобразное" изменение значений $\delta^{13} \mathrm{C}_{\text {орг. }}$.

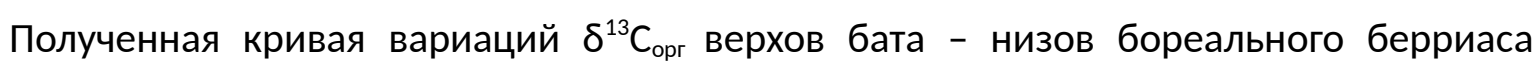
Анабарского разреза (рис. 4,8 ) практически идентична по трендам развития с таковой из разрезов залива Стаффин, о-ва Скай, Шотландия [Nunn et al., 2009]. Интересно отметить синхронные "качелеобразные" изменения значений $\delta^{13} \mathrm{C}_{\text {орг }}$ в низах разрезов оксфорда обоих регионов (рис. 8).

Седиментологические и биофациальные характеристики позволяют предполагать, что органическое вещество исследованных разрезов накапливалось в прибрежно-морских субокислительных обстановках, неблагоприятных для его концентрирования и сохранности в диагенезе. Согласно пиролитической информации, органическое вещество является незрелым. Для проб, в целом, характерен тяжелый изотопный состав углерода рассеянного органического вещества, что позволяет рассматривать его генотип как преимущественно террагенный (органическое вещество, обогащенное остатками высших растений) [Тиссо, Вельте, 1981; Конторович и др., 1986; Peters et al, 2005]. В тоже время, повышенные значения $\delta^{13} C_{\text {орг }}$ близкие к измеренным в исследованных образцах характеризуют незрелое органическое вещество как террагенного, так и аквагенного генотипа [Галимов, 1973; Environmtntal..., 2001]. Как известно [Тиссо, Вельте, 1981; Галимов, 1973; Environmental..., 2001], восстановительные условия способствуют увеличению роли анаэробного разложения захороняющегося биоматериала, которое благоприятно сказывается не только на сохранности органического вещества, но и приводит к обеднению изотопом ${ }^{13} \mathrm{C}$. Поэтому, наблюдаемая снизу-вверх, по разрезу $\mathrm{OK} / \mathrm{S} 2$, тенденция к обогащению изотопом ${ }^{13} \mathrm{C}$ органического вещества содиемыхаинской свиты может быть связана с его большей окисленностью. Пробы с пониженными для исследованной коллекции значениями $\delta^{13} \mathrm{C}_{\text {орг }}$ и одновременно повышенными значениями $\mathrm{C}_{\text {орг }}$ и пиролитического параметра $\mathrm{S}_{2}$ из волжской части буолкалахской свиты, повидимому, накапливались в более восстановительных условиях. 


\section{ЗАКЛЮЧЕНИЕ}

Проведенные комплексные стратиграфические исследования разреза верхов бата низов бореального берриаса позволили выявить последовательности из девяти биостратонов в ранге зон и слоев с диноцистами и с палинофлорой. Часть палинологических биостратонов установлена впервые. В исследованных Анабарских разрезах прослежены фораминиферовые комплексы зон бореального стандарта: верхов байоса - нижней части бата (JF22), верхов бата - келловея (JF25), верхов среднего и верхнего келловея (JF31/JF32), нижнего и основания верхнего оксфорда (JF36), средней части верхнего оксфорда (JF37), верхов оксфорда - нижней части нижнего кимериджа (JF40), верхов нижнего - верхнего кимериджа (JF41), низов нижневолжского подъяруса (JF44), верхов нижнего - нижней половины средневолжского подъяруса (JF45), верхов средневолжского подъяруса - основания бореального берриаса (JF52) и низов бореального берриаса (KF1). Полученные новые биостратиграфические данные и анализ всех известных находок аммонитов в этом разрезе позволили обосновать стратиграфическую непрерывность разреза изученного участка, несмотря на сокращенную мощность стратонов.

Уточнено стратиграфическое положение границы между содиемыхаинской и буолкалахской свитами. Глауконитовый песчаник с фосфоритами, включавшийся ранее в кровлю содиемыхаинской свиты, отнесен к базальным слоям буолкалахской свиты. Установлено значительное различие между содержаниями основных породообразующих окислов и ряда элементов-примесей в породах содиемыхаинской свиты и вышележащего базального пласта. Многие особенности химического состава последнего унаследованы породами низов буолкалахской свиты. Это меняет стратиграфическое понимание положения нижней границы буолкалахской свиты с нижней границы волжского яруса на верхи оксфорда - основание кимериджа. В такой интерпретации базальный горизонт буолкалахской свиты фиксирует новый крупный этап осадконакопления, изохронный нижним границам литостратонов разного ранга по всему Арктическому и частично Бореальному регионам.

Впервые проведен анализ литогеохимического состава верхнебатско-берриасских толщ. По геохимической характеристике верхи юрюнгтумусской, содиемыхаинской и низы буолкалахской свит оказались неоднородны, что отражает особенности седиментогенеза. Содержание породообразующих элементов характеризуется довольно резкими изменениями в отдельных интервалах разреза. Установлено, что верхи юрюнгтумусской свиты относятся к кварцевым грауваккам, тогда как породы содиемыхаинской свиты являются полевошпатовыми грувакками, а буолкалахской - отнесены к полевошпатокварцевому типу.

Содержание $\mathrm{C}_{\text {орг }}$ В исследованных образцах не превышает его кларковых значений.

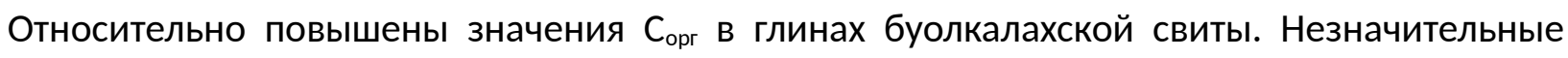

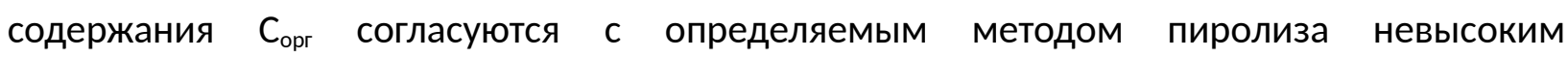
нефтегазогенерационным потенциалом исследованных пород, а пиролитический показатель $\mathrm{T}_{\max }$ свидетельствует о низкой зрелости органического вещества. 
Седиментологический и биофациальный анализ позволяет сделать вывод, что органическое вещество накапливалось в прибрежно-морских субокислительных обстановках. Исследованное органическое вещество пород характеризуется тяжелым изотопным составом углерода, что позволяет предполагать его преимущественно террагенный генотип. Относительно пониженные значения $\delta^{13} \mathrm{C}_{\text {орг }}$ и восстановительный режим седиментогенеза характерны для волжской части буолкалахской свиты. Кривая вариаций $\delta^{13} \mathrm{C}_{\text {орг }}$ на разрезах верхов бата - низов бореального берриаса Анабарского разреза практически идентична по трендам развития с таковой из разрезов залива Стаффин, о-ва Скай, Шотландия.

Авторы искренне признательны В.А. Каширцеву и В.В. Сапьянику за ценные рекомендации, способствовавшие улучшению рукописи статьи. Исследования выполнены при финансовой поддержке РНФ, проекты 18-17-00038; 19-17-00091 и РФФИ, проект 18-0570035. 


\section{ЛИТЕРАТУРА}

Бодылевский В.И. Келловейские аммониты Северной Сибири // Записки Ленинградского Горного Ин-та, 1960, т. XXXVII, вып.2, с.49-82.

Болховитина Н.А. Спорово-пыльцевые комплексы мезозойских отложений Вилюйской впадины и их значение для стратигарфии. М., Труды ГИН, 1959, вып. 24, 187 с.

Васильева Н.С. Мезозойские спрово-пыльцевые комплексы Южной Прибалтики и их стратиграфическое значение // Хлонова А.Ф. (Ред.) Палинология мезофита. Труды III Международной палинологической конференции. М., Наука, 1973, с. 104-108.

Вассоевич Н.Б. Исходное вещество для нефти и газа // Происхождение нефти и газа и формирование их месторождений. (Материалы Всесоюзного совещания по генезису нефти и газа) / Гл. ред. М.Ф. Мирчинк. М.: Недра, 1972, с. 39-70

Вержбовский А., Рогов М.А. Биостратиграфия и аммониты среднего оксфорда - нижней части кимериджа Средней Сибири // Геология и геофизика, 2013, т. 54 (8), с. 1381-1403.

Воронец Н.С. Стратиграфия и головоногие моллюски юрских и нижнемеловых отложений ЛеноАнабарского района. Труды НИИГА, 1962, т.110, М.: Госгеолтехиздат, 237 с.

Воронова М.А. Миоспоры раннего мела Украины. Киев, Наукова думка, 1984, 120 с.

Галимов Э.М. Изотопы углерода в нефтегазовой геологии. М.: Недра, 1973, 384 с.

Глушко Н.К. Эталонные спрово-пыльцевые комплексы келловея и вопросы ботаникогеографической зональности Западной Сибири // Бочкарев В.С. (Ред.) Палинологические исследования мезозоя и кайнозоя Западной Сибири. Тюмень, 1980, ЗапСибНИгНИ, вып. 149, с. 1926.

Глушко Н.К., Пуртова С.И. Сопоставление спорово-пыльцевых комплексов из осадков баженовской и тутлеймской свит // Бочкарев В.С. (Ред.) Палинологические исследования мезозоя и кайнозоя Западной Сибири. Тюмень, 1980, ЗапСибНИгНИ, вып. 149, с. 30-36.

Гольберт А.В., Климова И.Г., Булынникова С.П., Девятов В.П., Турбина А.С. Морские волжские и неокомские отложения бассейна р.Буолкалах (Арктическая Якутия) // Геология и нефтегазоносность мезозойских седиментационных бассейнов Сибири, 1983, труды ИГиГ СО АН СССР, вып.532, с.48-58.

Духанин С.Ф. Государственная геологическая карта СССР масштаба 1:200 000. Серия Оленекская. Лист S-50-XXXI, XXXII. Объяснительная записка. Л., изд-во ВСЕГЕИ, 1976а, 49 с.

Духанин С.Ф. Государственная геологическая карта СССР. Масштаб 1:200 000. Оленекская серия. S-50-XXXI, XXXII (Улахан-Кюель). Ленинград, ВСЕГЕИ. 19766.

Ильина В.И. Палинология юры Сибири. М., Наука, 1985, 237 с.

Кара-Мурза Э.Н. Некоторые данные о составе спорово-пыльцевых комплексов морского нижнего мела отдельных участков Нордвикского района // Шведов Н.А. (ред.) Сборник статей по палеонтологии и биостратиграфии. Л., НИИГА, 1958, вып. 10, с. 27-44.

Киселев Д.Н. Аммониты и биостратиграфия келловейских отложений (р. Сысола у с. Вотча, Русская платформа) // Новости палеонтологии и стратиграфии. Приложение к журн. "Геология и геофизика", 2006, т. 47, вып. 9, с. 47-69.

Князев В.Г. Аммониты и зональная стратиграфия нижнего оксфорда севера Сибири. Труды ИГиГ СО АН СССР, 1975, вып.275, М.: Наука, 139 с.

Князев В.Г., Меледина С.В., Месежников М.С., Сакс В.Н. О зональном расчленении пограничных слоёв келловея и оксфорда на севере СССР // Доклады АН СССР. Геология, 1973, т. 209, №3, с. 655-658.

Князев В.Г., Меледина С.В., Алифиров А.С., Никитенко Б.Л. Раннекелловейский род Cadochamoussetia (Ammonoidea, Cardioceratidae) в низовьях р. Анабар, север Средней Сибири // Стратиграфия. Геологическая корреляция, 2017, т. 25, № 4, с. 26-41.

Князев В.Г., Меледина С.В., Алифиров А.С. Средний келловей Сибири: аммониты и зональное деление // Стратиграфия. Геологическая корреляция, 2020, т. 28, № 3, с. 63-81.

Комплексные исследования стратиграфии юры и нижнего мела Западной Сибири. / Корж М.В. (ред.). М.: Наука, 1978, 140 с. 
Конторович А.Э., Верховская Н.А., Тимошина И.Д., Фомичев А.С. Изотопный состав углерода рассеянного органического вещества и битумоидов и некоторые спорные вопросы теории образования нефти// Геология и геофизика, 1986, № 5, с. 3-13

Короткевич В.Д. Палинологическая характеристика морских юрских и нижнемеловых отложений, вскрытых скважинами на Тюмятинском и Улахан-Юряхском участках (Лено-Оленекский район) // Шведов Н.А. (Ред.) Сб. статей по палеонтологии и биостратишрафии. Л., НИИГА, 1963, вып. 32, с. 24-37.

Костеша О.Н., Кабанова Л.Г., Ткачева В.С., Чеснокова В.С. Новые данные по палиностратиграфии нижней части осадочного чехла юго-востока западной Сибири // Гурари Ф.Г. (Ред.) Геология и нефтегазрносность триас-среднеюрских отложений Западной Сибири. Новосибирск, СНИИГГиМС, 1991, с. 55-63.

Левчук М.А. Литология и перспективы нефтегазоносности юрских отложений ЕнисейХатангского прогиба. Труды ИГиГ СО АН СССР, 1985, вып.624, Новосибирск: Наука, 1985, 164 с.

Лопатин Н.В., Емец Т.П. Пиролиз в нефтегазовой геохимии. М.: Наука, 1987, 144 с.

Лутова 3.В. Комплекс фораминифер с Conorboides taimyrensis Lutova sp. N. из верхнего келловея севера Средней Сибири // Геология и геофизика, 1976, №1, с.112-121.

Лутова 3.В. Стратиграфия и фораминиферы келловея севера Средней Сибири. Труды ИГиГ СО АН СССР, 1981, вып.472, М.: Наука, 1981, 235 с.

Любомирова К.А., Кисляков В.Н. Результаты палинологического изучения нижнемеловых отложений северной части Лено-Анабарского прогиба // Палинологические исследования отложений палеозоя и мезозоя Севера СССР и Прикаспия. Ленинград, ВНИГРИ, 1985, с. 70-79.

Маркевич В.С. Меловыне флоры Восточной Азии. Владивосток, Дальнаука, 1995, 200 с.

Меледина С.В. Аммониты и зональная стратиграфия келловея Сибири. Труды ИГиГ СО АН СССР, 1977, вып.356, М.: Наука, 290 с.

Месежников М.С. Кимериджский и волжский ярусы севера СССР. Л., Недра. 1984. 205 с.

Месежников М.С., Азбель А.Я., Калачева Е.Д., Ротките Л.М. Средний и верхний оксфорд Русской платформы. Труды МСК,1989, т.19, Л.: Наука, 183 с.

Никитенко Б.Л. Стратиграфия, палеобиогеография и биофации юры Сибири по микрофауне (фораминиферы и остракоды). Новосибирск, Параллель, 2009, 680 с.

Никитенко Б.Л., Князев В.Г., Лебедева Н.К., Пещевицкая Е.Б., Кутыгин Р.В. Проблемы стратиграфии оксфорда и кимериджа на севере Средней Сибири (разрез полуострова Нордвик) // Геология и геофизика, 2011, т. 52, № 9, с.1222-1241.

Никитенко Б.Л., Шурыгин Б.Н., Князев В.Г., Меледина С.В., Дзюба О.С., Лебедева Н.К., Пещевицкая Е.Б., Глинских Л.А., Горячева А.А., Хафаева С.Н. Стратиграфия юры и мела Анабарского района (арктическая Сибирь, побережье моря Лаптевых) и Бореальный зональный стандарт // Геология и геофизика, 2013, т.54, № 8, с. 1047-1082.

Никитенко Б.Л., Князев В.Г., Пещевицкая Е.Б., Глинских Л.А., Кутыгин Р.В, Алифиров А.С. Высокоразрешающая стратиграфия верхней юры побережья моря Лаптевых // Геология и геофизикаю - 2015а. - Т. 56, № 4 - С. 845-872.

Никитенко Б.Л., Князев В.Г., Пещевицкая Е.Б., Глинских Л.А. Верхняя юра побережья моря Лаптевых: межрегиональные корреляции и палеообстановки // Геология и геофизика. - 2015б. - Т. 56, № 8. - С. $1496-1519$

Никитенко Б.Л., Девятов В.П., Родченко А.П., Левчук Л.К., Пещевицкая Е.Б., Фурсенко Е.А. Гольчихинская свита (верхи бата - низы бореального берриаса) Енисей-Хатангского прогиба (запад Северо-Сибирской низменности) // Геология и геофизика. - 2020. - Т. 61, № 4. - С. 508-526

Опороный разрез неокома севера Сибирской платформы (Енисей-Хатангский прогиб, АнабароХатангская седловина). Геологическое описание. Том 2. / Ред. А.В. Гольберт. Новосибирск, СНИИГГиМС, 1981, 134 с.

Осадочные породы (классификация, характеристика, генезис). / Ред. В.И. Богатова. Новосибирск: Наука, 1987, 214 с.

Павлов А.П. Юрские и нижнемеловые Cephalopoda Северной Сибири // Записки Императорской Академии наук, 1914, серия VII, т.XXI, №4, Научные результаты Русской Полярной Экспедиции 1900-1903 гг., под начальством барона Э.В. Толля. Отдел С: Геология и Палеонтология, вып. 4, СПб., 68 с. 
Пещевицкая Е.Б. Диноцисты и палиностратиграфия нижнего мела Сибири. Новосибирск, Изд-

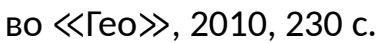

Пещевицкая Е.Б. Палиностратиграфия и палеообстановки в разрезе Городищи (Среднее Поволжье, кимеридж-готерив) // Геология и геофизика, 2020. В печати. DOI: 10.15372/GiG2019174

Пуртова С.И., Игнатова М.М. Комплексы спор и пыльцы из юрских отложений восточной части Западно-Сибирской равнины // Бочкарев В.С., Пуртова С.И. (Ред.) Биостратиграфия мезозоя Западной Сибири. Сб. научных трудов. Тюмень, 1987, ЗапСибНИГНИ, с. 27-30.

Решения и труды Межведомственного совещания по доработке и уточнению унифицированной и корреляционной стратиграфических схем Западно-Сибирской низменности. Часть 1. / Ред. Н.Н. Ростовцев, Тюмень. 1969. 143 с.

Решения 3-го Межведомственного регионального стратиграфического совещания по мезозою и кайнозою Средней Сибири / Ред. В.Н. Сакс. Новосибирск, СНИИГГиМС, 1981, 91 с.

Решение 6-го Межведомственного стратиграфического совещания по рассмотрению и принятию уточненных стратиграфических схем мезозойских отложений Западной Сибири (Новосибирск, 2003 г.) /Ред. Ф.Г. Гурари. Новосибирск, СНИИГГиМС, 2004, 114 с.

Рогов М.А. Аммониты и инфразональная стратиграфия кимериджского и волжского ярусов панбореальной надобласти. Автореферат диссертации на соискание ученой степени доктора геол.мин. наук. М.: 2019, 46 с.

Сакс В.Н., Ронкина 3.3., Шульгина Н.И., Басов В.А., Бондаренко Н.М. Стратиграфия юрской и меловой системы севера СССР. М.-Л., Изд-во АН СССР, 1963, 227 с.

Смокотина И.В. Палиностратиграфия юрских отложений Кансо-Ачинского бассейна. Красноярск, Красноярскгеолсъемка, 2006, 97 с.

Споры и пыльца юры и раннего мела Средней Азии. (ред. Болховитина, Фокина) Труды ВНИГНИ. М., Недра, 1971, вып. 104, 176 с.

Справочник по геохимии нефти и газа / Ред. С.Г. Неручев. СПб: ОАО «Недра», 1998, 576 с.

Стратиграфия юрской системы Севера СССР / Ред. В.Н. Сакс. М., Наука, 1976, 436 с.

Стратиграфо-палеонтологическая основа детальной корреляции нефткгазоносных отложений Западно-Сибирской низменности/ Лебедев И.В. (ред.), Тюмень, ЗапСибНИГНИ, 1972, вып. 48, 227 с.

Тиссо Б., Вельте Д. Образование и распространение нефти. М.: Мир, 1981, 501 с.

Толль Э.В. Экспедиция Императорской Академии наук 1893 года на Ново-Сибирские острова и побережье Ледовитого океана (от Св. Носа до Хатангской губы) // Известия Императорского Русского географического общества, 1894, т.30, вып.4, СПб., с. 435-451

Толль э.В. Очерк геологии Ново-Сибирских островов и важнейшие задачи исследования полярных стран // Записки Императорской Академии наук, 1899, т.ІХ, №1, СПб., с.1-20.

Фрадкина А.Ф. Спорово-пыльцевые комплексы мезозоя Западной Якутии. Л., Недра, 125 с.

Шаровская Н.В. Некоторые виды аммодисцид и медуонид из мезозойских отложений севера Центральной Сибири // Ученые записки НИИГА, серия палеонтология и биостратиграфия, 1966, вып.14, с.48-74.

Шатова Л.А. Спорово-пыльцевые комплексы юрских отложений юго-восточной части ЕлогуйЕнисейского района // Пуртова С.И. (Ред.) Палинологические критерии в биостратиграфии Западной Сибири. Тюмень, ЗапСибНИгНИ, 1994, с. 59-64.

Шейко Л.Н. Районирование Запално-Сибирской равнины по типам юрских спорово-пыльцевх комплексов // Бочкарев В.С. (Ред.) Палинологические исследования мезозоя и кайнозоя Западной Сибири. Тюмень, ЗапСибНИгНИ, 1980, вып. 149. с. 11-18.

Шейко Л.Н., Шатова Л.А. Новые палинологические данные по юрским отложениям Сургутского свода // Бочкарев В.С., Пуртова С.И. (Ред.) Биостратиграфия мезозоя Западной Сибири. Сб. научных трудов. Тюмень, ЗапСибНИГНИ, 1987, с. 45-47.

Шурыгин Б.Н., Никитенко Б.Л., Девятов В.П., Ильина В.И., Меледина С.В., Гайдебурова Е.А., Дзюба О.С., Казаков А.М., Могучева Н.К. Стратиграфия нефтегазоносных бассейнов Сибири. Юрская система. Новосибирск, Гео, 2000, 480 с.

Шутов В.Д. Классификация песчаников // Литология и полезные ископаемые, 1967, № 5, с. 86103.

Abbink O.A. Palynological investigations in the Jurassic of the North Sea region. Utrecht, LPP Foundation, 1998, $192 \mathrm{p}$. 
Abbink O.A., Callomon J.H., Riding J.B., Williams P.D.B., Wolfard A. Biostratigraphy of JurassicCretaceous boundary strata in the Ter-schelling Basin, The Netherlands // Proceedings of the Yorkshire Geological Society, 2001, v. 53, no. 4, p. 275-302.

Batten D.J. Upper Jurassic and Cretaceous miospores // Jansonius J., McGregor D.C. (Eds.) Palynology: principles and applications, in 3 volumes, Salt Lake City, AASP, 1996, v. 2, p. 807-831.

Bujak J.P., Williams G.L. Jurassic palynostratigraphy of offshore eastern Canada // Swain E.W. (Ed.) Stratigraphic Micropalaeontology of Atlantic Basin and Borderlands. Amsterdam, Elsevier, 1977, p. 321339.

Burden E.T., Hills L.V. Illustrated key to genera of Lower Cretaceousterrestrial palynomorphs (excluding megaspores) of Western Canada. AASP Contributions Series, 1989, v. 21, 147 pp.

Courtinat B. Review of the dinoflagellate cyst Stephanelytron Sarjeant 1961 emend // Journal of Micropalaeontology, 1999, v.18, pt. 2, p.169-182.

Davies E.H. The dinoflagellate Oppel-zonation of the Jurassic-Lower Cretaceous sequences in the Sverdrup Basin, Arctic Canada // Geological Survey of Canada, 1983, bul. 359, p. 1-59.

Dodekova L. Dinoflagellate cysts from the Bathonian-Tithonian (Jurassic) of north Bulgaria. I. Taxonomy of Bathonian and Callovian dinoflagellate cysts // Geologica Balcanica, 1990, v. 20, no. 2, p. 345.

Dodekova L. Dinoflagellate cysts from the Bathonian-Tithonian (Jurassic) of North Bulgaria. II. Taxonomy of Oxfordian and Kimmeridgian dinoflagellate cysts // Geologia Balcanica, 1992, v. 22, no. 3, p. 33-69.

Dorhofer G. Palynologie und stratigraphie der Buckeberg-Formation (Berriasium-Valanginium) in The Hilsmulde (Nw, Deutschland) // Geologisches Jahrbuch, 1977, v. 42, p. 3-122.

Dorhofer G. Distribution and stratigraphic utility of Oxfordian toValanginian miospores in Europe and North America // AASP Contributions Series, 1979, v. 2, p. 101-132.

Duxbury S. A palynostratigraphy of the Berriasian to Barremian of the Speeton Clay of Speeton, England // Palaeontographica, Ab. B, 1977, band 160, lief. 1-3, p. 17-67.

Environmtntal isotopes in the hydrological cycle. Principles and applications. Volume I. Introduction: Theory, Methods, Review / Ed. by W.G. Mook. Paris, UNESCO/ IAEA, 2001, 280 p.

Fauconnier D. Jurassic palynology from a borehole in the Champagne Area, France. Correlation of the Lower Callovian - Middle Oxfordian using sequence stratigraphy // Review of Palaeobotany and Palynology, 1995 , v. 87 , no. 1, p. 15-26.

Filatoff J. Jurassic palynology of the Perth Basin, Western Australia // Palaeontographica, Ab. B, 1975, v. 154 , no. 1. p. 1- 113.

Heilmann-Clausen C. Lower Cretaceous dinoflagellate biostratigraphy in the Danish Central Trough // Denm. Geol. Unders., 1987, v. 17, p. 1-89.

Herngreen G.F.W., Kerstholt S.J., Munsterman D.K. Callovian-Ryazanian (Upper Jurassic) palynostratigraphy of the Central North Sea Graben and Vlieland Basin, the Netherlands // Mededel. Nederl. Instit. Toegepaste Geowetenschappen, 2000, v. 63, p. 1-97.

Herngreen G.F.W., de Boer K.F. Zonacion del Dogger Superior y del Malm ?Basal en los Paises Bajos a Base de dinoflagelados, Palinologia, Numero extraordinario, 1978, no. 1, p. 283- 291.

Ilyina V.I., Nikitenk, B.L., Glinskik, L.A. Foraminifera and dinoflag-ellate cyst zonation and stratigraphy of the Callovian to Volgian referencesection in the Tyumenskaya superdeep well (West Siberia, Russia) // Powell A.J., Riding J.B. (Eds.) Recent Developments in Applied Biostratigraphy. The Micropalaeontological Society, Spec. Issue, 2005, p. 109-144.

Larsen M., Piasecki S., Surly F. Stratigraphy and sedimentology of a basement-onlapping shallow marine sandstone succession, the Charcot Bugt Formation, Middle-Upper Jurassic, East Greenland // Geological Survey of Denmark and Greenland Bulletin, 2003, no. 1, p. 893-930.

Lebedeva N.R., Nikitenko B.L., Colpaert C. Dinoflagellate cysts and Foraminifera of the Upper Jurassic Lopsiya River sections, Nether-Polar Urals, NW Western Siberia (Russia) // Revue de Micropaléontologie, 2019, v.64, 100361.

Lund J.J., Pedersen K.R. Palynology of the marine Jurassic Formations in the Vardekloft Ravine, Jameson Land, East Greenland // Geological Society of Denmark, Bulletin, 1985, v. 33, p. 371- 399 
Monteil E. Dinoflagellate cyst biozonation of the Tithonian and Berriansian of south-east France, correlation with the sequence stratigraphy // Bulletin des Centres de Recherches Exploration-Production Elf-Aquitaine, 1993, p. 249-273.

Nikitenko B.L., Pestchevitskaya E.B., Lebedeva N.K., Ilyina V.I. Micropalaeontological and palynological analyses across the Jurassic-Cretaceous boundary on Nordvik Peninsular, Northeast Siberia // Newsletters on Stratigraphy, 2008, v. 42, N. 3, p. 181-222

Nikitenko B.L., Pestchevitskaya E.B., Khafaeva S.N. High-resolution stratigraphy and palaeoenvironments of the Volgian - Valanginian in the Olenek section (Anabar-Lena region, Arctic Eastern Siberia) // Revue de Micropalaeontology, 2018, v. 61. p. 271-312.

Norris G. Miospores from the Purbeck beds abd marine Upper Jurassic of Southern Englans // Palaeontology, 1969, v. 12, part 4, p. 574-621.

Norris G. Palynologic creteria for recognition of the Jursassic-Cretaceous boundary in Western Europe // Хлонова А.Ф. (Ред.) Палинология мезофита. Труды III Международной палинологической конференции. М., Наука, 1973, с. 97-101.

Nunn E.V., Price G.D., Hart M.B., Page K.N., Leng M.J. Isotopic signals from Callovian-Kimmeridgian (Middle-Upper Jurassic) belemnites and bulk organic carbon, Staffin Bay, Isle of Skye, Scotland // Journal of the Geological Society, London, Vol. 166, 2009, pp. 633-641.

Peters K.E. Guidelines for evaluating petroleum source rock using programmed pyrolysis // AAPG Bulletin, 1986, v. 70, p. 318-329

Peters K.E., Walters C.C., Moldowan J.M. The biomarker guide. 2nd ed. NY: Cambridge University Press, 2005, v. 2, 1155 p.

Piasecki S., Callomon J.H., Stemmerik L. Jurassic dinoflagellate cyst stratigraphy of Store Koldewey, North-East Greenland // Geological Survey of Denmark and Greenland Bulletin, 2004, v. 5, p. 99-112.

Poulsen N.E. Dinoflagellate cyst biostratigraphy of the Oxfordian and Kimmeridgian of Poland // Acta Geologica Polonica, 1993, v. 43, no. 3, p. 251-272.

Poulsen N.E. Dinoflagellate cysts from marine Jurassic deposits of Denmark and Poland // AASP Contributions Series, 1996, v. 31, 1-227.

Poulsen N.E., Riding J.B. The Jurassic dinoflagellate cyst zonation of Subboreal Northwest Europe // Ineson J.R., Surlyk F. (eds.) The Jurassic of Denmark and Greenland, Geological Survey of Denmark and Greenland Bulletin, 2003, v. 1, p. 115-144.

Powell A.J. (Ed.) A stratigraphic index of dinoflagellate cysts. London, Chapmanand Hall, 1992, 290 pp.

Prauss M. Dinozysten-Stratigraphie und Palynofazies im Oberen Lias und Dogger von NWDeutschland // Palaeontographica, Ab. B, 1989, v. 214, band 1, p. 1-124.

Riding J.B. Jurassic dinoflagellate cysts of Skye, Western Scotland - the key to the north-west margin // British Geological Survey, Stratigraphical Masterpack, 1991, v. 1, p. 1-141.

Riding J.B. Dinoflagellate cyst stratigraphy of the Nettleton Bottom borehole, (Jurassic--Hettangian to Kimmeridgian), Lincolnshire, England // Proceedings of the Yorkshire Geological Society, 1987, v. 46, no. 3, p. 231-266.

Riding J.B., Thomas J.E. Dinoflagellate cyst stratigraphy of the Kimmeridge Clay, (Upper Jurassic) from the Dorset Coast, southern England // Palynology, 1988, v. 12, p. 65-88.

Riding J.B., Federova V.A., Ilyina V.I. Jurassic and lowermost Cretaceous dinoflagellate cyst biostratigraohy of the Russian Platform andnorthern Siberia, Russia // AAPS Contribution ser., 1999, v. 36, $184 \mathrm{pp}$.

Riding J.B., Mantle D.J., Backhouse J. A review of the chronos-tratigraphical ages of Middle Triassic to Late Jurassic dinoflagellate cystbiozones of the North West Shelf of Australia // Review of Palaeobotany and Palynology, 2010, v. 162, p. 543-575.

Riley L.A., Fenton J.P.G. (A dinocyst zonation for the Callovian to Middle Oxfordian succession, (Jurassic), of Northwest Europe // Palynology, 1982, v. 6, p. 193- 202.

Sajjadi F., Playford G. Systematic and stratigraphic palynology of Late Jurassic - earliest Cretaceous strata of the Eromanga Basin, Queensland, Australia, Part two // Palaeontographica, Ab. B, 2002, v. 261, p. 99-165.

Sarjeant W.A.S. Middle and Upper Jurassic dinoflagellate cyst // AASP Contributions Series, 1979, v. 2, no. 5, p. 133-156. 
Schrank E. Pollen and spores from the Tendaguru beds, Upper Jurassic and Lower Cretaceous of Tanzania: palynostratigraphical and palaeoecological implications // Palynology, 2010, v. 34, p. 3-42.

Scotese C.R. Paleogeographic and Paleoclimatic Atlas // AAPG Data Pages. Search and Discovery Article\#30192(2011). http://www.searchanddiscovery.com/pdfz/documents /2011/30192scotese/ndx_scotese.pdf.html

Smelror M., Larssen G.B., Olaussen S., Romuld A., Williams R. Late Triassic to Early Cretaceous palynostratigraphy of Kong Karls Land, Svalbard, Arctic Norway, with correlations to Franz Josef Land, Arctic Russia // Norwegian Journal of Geology, 2018, v. 98, p. 1-3.

Smelror M. Bathonian to Early Oxfordian dinoflagellate cysts and acritarchs from Kong Karls Land, Svalbard // Review of Palaeobotany and Palynology, 1988a, v. 56, p. 275-304.

Smelror M. Late Bathonian to Oxfordian dinoflagellate cyst stratigraphy of Jameson Land and Milne Land, East Greenland // Grundlands geol. Urdens. 1988b, v. 137, p. 135-159.

Smelror M. Chlamydophorella ectotabulata sp. nov., a gonyaulacoid dinoflagellate cyst from the late Bathonian to the Oxfordian of the Arctic // Rev. Palaoeobot. Palynol., 1989, v. 61, p. 139-145.

Smelror M. Biogeography of Bathonian to Oxfordian (Jurassic) dinoflagellates: Arctic, NW Europe and circum-Mediterranean regions // Palaeogeography, Palaeoclimatology, Palaeoecology, 1993, v. 102, p. 121-160.

Smelror M., Aarhus N. Emendation of the dinoflagellate cyst genus Crussolia Wolfard \& Van Erve 1981, and description of C. dalei n. sp. from the Callovian of Svalbard // Neues Jahrbuch für Geologie und Paläontologie, Monatshefte, 1989, no.1, p. 37-46.

Smelror M., Below R. Dinoflagellate biostratigraphy of the Toarcian to Lower Oxfordian (Jurassic) of the Barents Sea Region. In: Arctic Geology and Petroleum Potential // Nor. Pet. Soc. Spec. Publ., 1992, no. 2, p. 493-511.

Srivastava S.K. Jurassic spore-pollen assemblages from Normandy, (France and Germany) // Geobios, 1987 , v. 20, p. $5-79$.

Thomas J.E., Cox B.M. The Oxfordian-Kimmeridgian Stage boundary (Upper Jurassic) -Dinoflagellate cyst assemblages from the Harome borehole North Yorkshire, England // Review of Palaeobotany and Palynology, 1988 , v. 56, no. 3, p. 313-326.

Van Helden B.G.T. Dinoflagellate cysts at the Jurassic-Cretaceous boundary, offshore Newfoundland, Canada // Palynology, 1986, v. 10, p. 181-199.

Williams G.L., Fensome R.A., MacRae R.A. The Lentin and Williams Index of Fossil Dinoflagellates 2017 Edition // AASP Contributions Series, 2017, no. 48, p. 1097.

Woollam R., Riding J.B. Dinoflagellate cyst zonation of the English Jurassic // Institute of Geological Sciences, Report, 1983, v. 83, p. 1-41. 
Подписи к рисункам и таблицам к статье Б.Л. Никитенко, В.П. Девятов, Е.Б. Пещевицкая, А.Ю. Попов, Е.А. Фурсенко, С.Н. Хафаева. СТРАТИГРАФИЯ, ЛИТОЛОГИЯ И ГЕОХИМИЯ ПРИБРЕЖНО- И МЕЛКОВОДНО-МОРСКИХ РАЗРЕЗОВ ВЕРХОВ СРЕДНЕЙ ЮРЫ - НИЗОВ МЕЛА Р. АНАБАР (АРКТИЧЕСКАЯ СИБИРЬ).

Рис. 1. Положение изученных разрезов средней юры - низов мела на р. Анабар (А) на геологической карте (Б) по [Духанин, 1976а, б] с изменениями и уточнениями и панорамный вид естественных выходов А9 и OK/S2.

Условные обозначения: 1. - балыктахская свита; 2. - содиемыхаинская свита; 3. - юрюнгтумусская свита; 4. изученные обнажения.

Рис. 2. Послойная характеристика строения разрезов A9 и OK/S2 верхов юрюнгтумусской, содиемыхаинской и низов буолкалахской свит

Условные обозначения: 1. - песок косослоистый; 2. - песок; 3. - песок алевритистый; 4. - алеврит песчаный; 5. - алеврит; 6. - алеврит глинистый; 7. - глина; 8 - алевролит песчаный и песчаник алевритистый известковистый; 9. - песчаник известковистый; 10. - известковистые и сидеритовые конкреции (а), галька и гравий (б), фосфоритовые конкреции и стяжения (в), брекчированные внедрения (г); 11. - глауконит (а), пирит (б), прослои и линзы угля (в); 12. - аммониты (а), двустворки (б), ростры белемнитов (в), скопления двустворок (г); 13. - стволы древесины (а), растительный детрит (б), трубки Dentalium (в), серпулы (г), следы жизнедеятельности: вертикальные (д) и горизонтальные (е); 14. - находки и определения аммонитов, сделанные предыдущими исследователями; 15. - находки аммонитов, сделанные авторами и определения аммонитов В.Г. Князева [Князев и др., 2017]; 16. - индекс фораминиферовой зоны, см рис. 7; 17. - индекс диноцистовой зоны, см. рис. 7; 18. - индекс палинозоны, см. рис. 7; слоистость: 19. - косая; 20. линзовидная; 21. - волнистая; 22. - нарушенная биотурбацией.

Рис. 3. Эволюция взглядов на биостратиграфическое (аммониты) и литостратиграфическое расчленение разрезов р. Анабар.

Рис. 4. Био- и литостратиграфическое расчленение разрезов верхов юрюнгтумусской, содиемыхаинской и низов буолкалахской свит в обнажениях A9 и OK/S2 и вариации геохимических параметров.

Усл. обозн. см. на рис. 2.

Рис. 5. Распределение основных таксонов диноцист в бате - низах бореального берриаса разреза А9.

Усл. обозн. см. на рис. 2.

Рис. 6. Распределение основных таксонов спор и пыльцы в бате - низах бореального берриаса разреза А9.

Усл. обозн. см. на рис. $2,5$.

Рис. 7. Стратиграфическая схема верхов бата-низов бореального берриаса бассейна р.Анабар

Условные обозначения:

1. - прибрежные, лагунные и субконтинентальные осадки; 2. - морские осадки

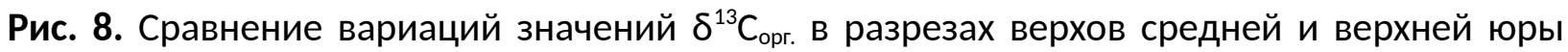
залива Стаффин, о-в Скай, Шотландия [Nunn et al., 2009] (1) и р.Анабар (2) (А) и глобальная 
палеогеография Северного Полушария в конце поздней юры и начале мела (Б) (палинспастические реконструкции, по [Scotese, 2011] с изменениями).

Табл. 1. Диноцистовые биостратоны и их биостратиграфическая характеристика.

Табл. 2. Спорово-пыльцевые биостратоны и их биостратиграфическая характеристика.

Табл. 3. Среднее содержание породообразующих окислов, элементов-примесей (с редкоземельными элементами).

Условные обозначения: 1 - направление возрастания и снижения содержаний компонента в разрезе; 2 высокие и повышенные содержания компонентов относительно всего разреза; 3 - высокие и повышенные содержания компонентов относительно разреза свиты; 4 - низкие и пониженные содержания компонентов относительно всего разреза; 5 - низкие и пониженные содержания компонентов относительно разреза свиты. 


\begin{tabular}{|c|c|c|}
\hline Зоны, слои с ДК & Нижняя граница & арактерные черты комплекса и стратиграфически важные признаки \\
\hline $\begin{array}{l}\text { 3она Sirmiodinium } \\
\text { grossii, верхня часть } \\
\text { бата - низы келловея, } \\
\text { мощность } 1.3 \text { м; } \\
\text { впервые установлена в } \\
\text { Баренцевоморском } \\
\text { pегионе [Smelror, } \\
\text { Below, 1992]. } \\
\text { Pаспространение: } \\
\text { Земля Франца Иосифа, } \\
\text { Шпицберген и } \\
\text { близлежащие острова, } \\
\text { Анабрский р-н } \\
\text { Восточной Сибири. }\end{array}$ & $\begin{array}{l}\text { Не прослежена, } \\
\text { определяется } \\
\text { началом отбора } \\
\text { образцов в нижней } \\
\text { части содиемыхаин- } \\
\text { ской свиты. По } \\
\text { первоописанию } \\
\text { зоны она } \\
\text { определяется по } \\
\text { появлению } \\
\text { Sirmiodinium grossii } \\
\text { и (локально) } \\
\text { Lacrimodinium } \\
\text { warrenii и } \\
\text { Valensiella dictydia, } \\
\text { верхняя - по } \\
\text { появлению } \\
\text { Meiourogonyaulax } \\
\text { planoseptata и } \\
\text { (локально) } \\
\text { Ambonosphaera } \\
\text { calloviana. }\end{array}$ & 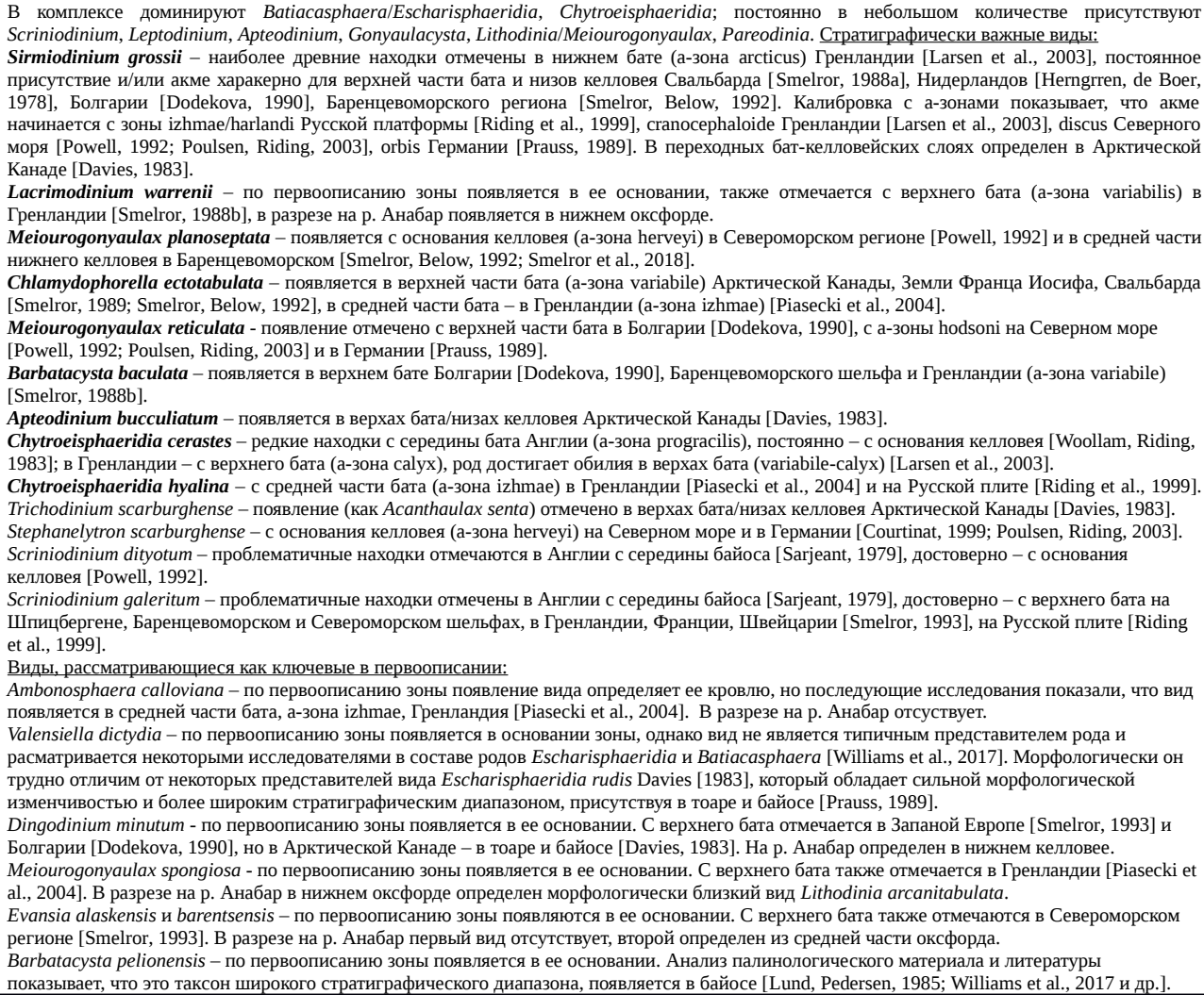 \\
\hline 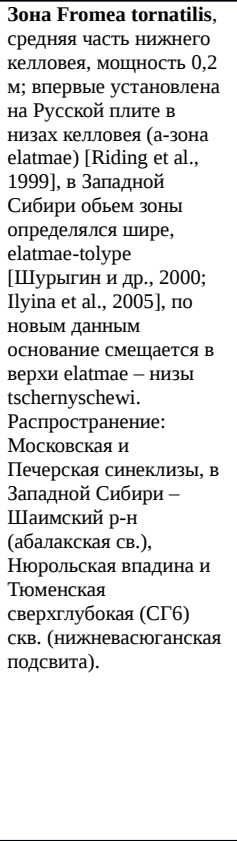 & $\begin{array}{l}\text { Основание по } \\
\text { первоописанию } \\
\text { определяется по } \\
\text { увеличению } \\
\text { количества Froтеа } \\
\text { tornatilis, по новым } \\
\text { данным также по } \\
\text { появлению } \\
\text { Meiourogonyaulax } \\
\text { planoseptata и } \\
\text { Yalkalpodinium; } \\
\text { кровля - на Русской } \\
\text { плите по появлению } \\
\text { Stephanelytron } \\
\text { callovianum, в скв. } \\
\text { СГ6 - также по } \\
\text { появлению } \\
\text { Impletosphaeridium } \\
\text { polytrichum, в } \\
\text { разрезе на р. Анабар } \\
\text { не прослежена. }\end{array}$ & 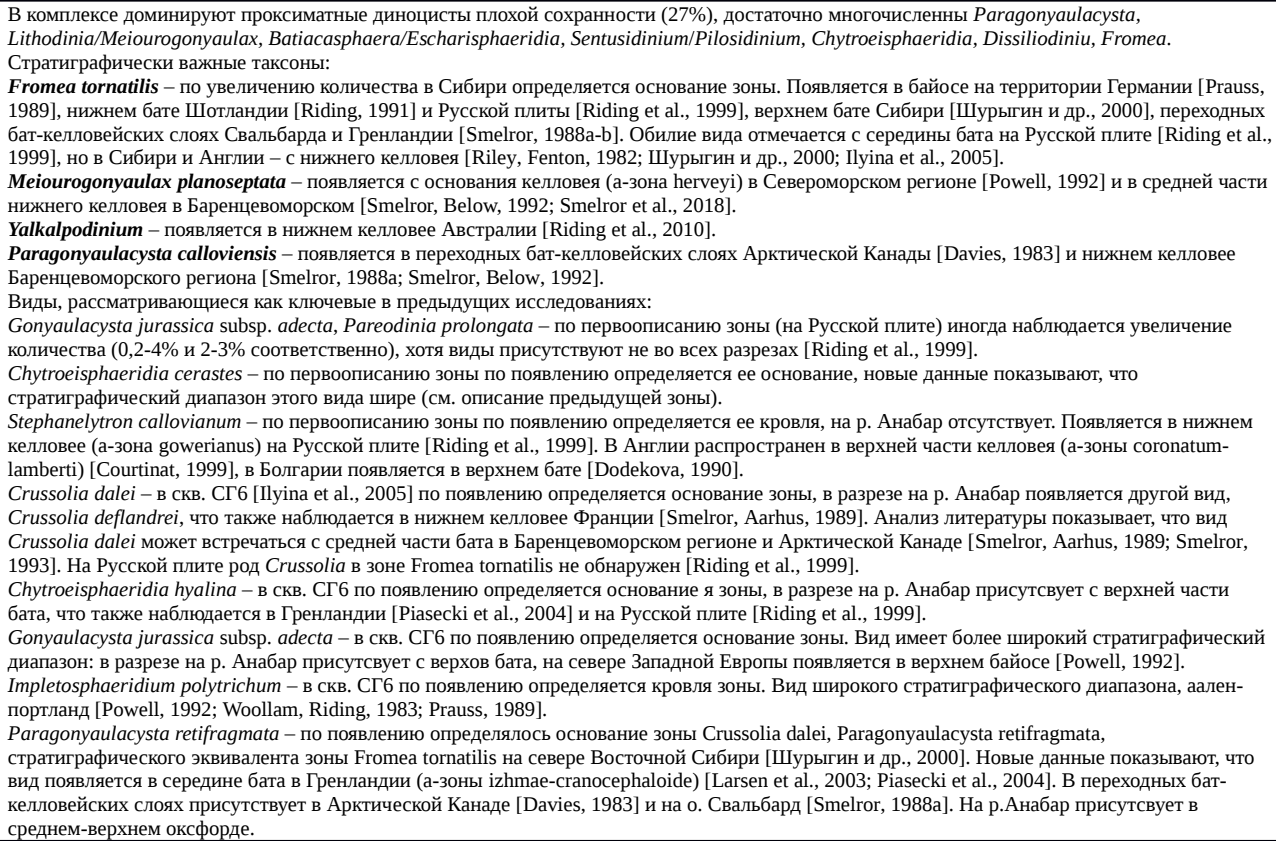 \\
\hline 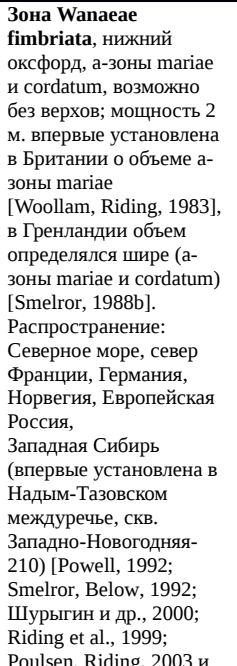 & $\begin{array}{l}\text { Основание - по } \\
\text { появлению Wanaea } \\
\text { fimbriata и началу } \\
\text { акме Trichodinium } \\
\text { scarburghense, } \\
\text { кровля - по } \\
\text { исчезновению } \\
\text { Wanaea fimbriata, } \\
\text { на Русской плите } \\
\text { дополнительно по } \\
\text { исеезновению } \\
\text { Gonyaulacysta } \\
\text { centriconnata и } \\
\text { появлению } \\
\text { Scriniodiniurn } \\
\text { luridum, в разрезе на } \\
\text { р. Анабар - по } \\
\text { исчезновению вида- } \\
\text { индекса, } \\
\text { Ctenidodinium } \\
\text { continuит, Evansia } \\
\text { barentsensis. }\end{array}$ & 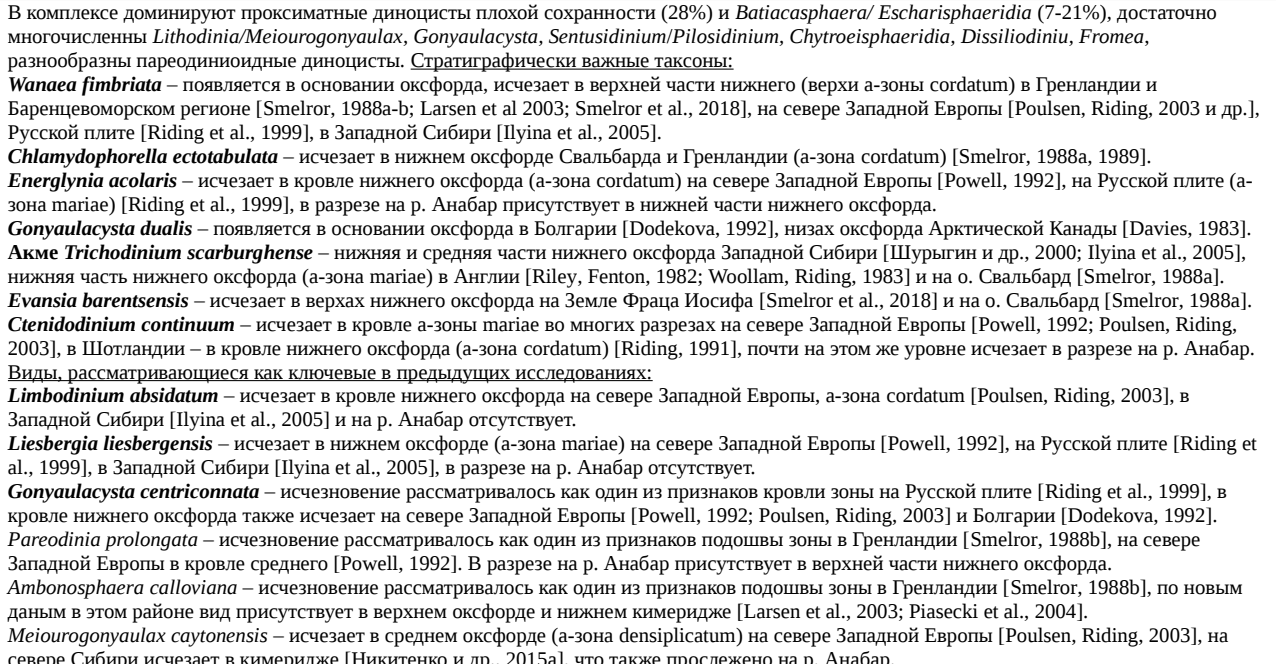 \\
\hline
\end{tabular}




\begin{tabular}{|c|c|c|}
\hline др.]. & & 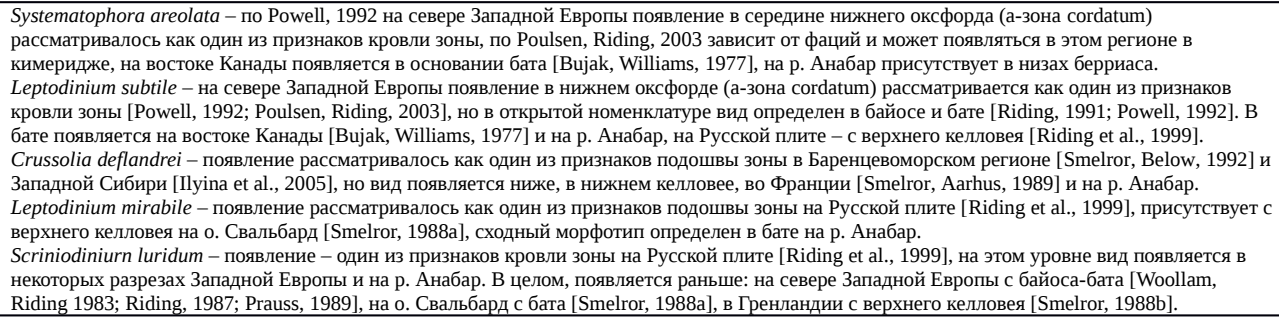 \\
\hline $\begin{array}{l}\text { Слои с } \\
\text { Cribroperidinium } \\
\text { granuligerum, средняя } \\
\text { часть среднего } \\
\text { оксфорда - низы } \\
\text { верхнего; мощность 2,3 } \\
\text { м; установлены } \\
\text { впервые. }\end{array}$ & $\begin{array}{l}\text { Основание - по } \\
\text { началу постоянных } \\
\text { (не единичных) } \\
\text { находок } \\
\text { Cribroperidinium } \\
\text { granuligerum; } \\
\text { кровля не } \\
\text { прослежена из-за } \\
\text { перерыва в } \\
\text { осадконакоплении. }\end{array}$ & $\begin{array}{l}\text { В комплексе доминируют проксиматные диноцисты плохой сохранности (12-23\%), достаточно много Lithodinia/Meiourogonyaulax, } \\
\text { Batiacasphaera/Escharisphaeridia, Sentusidinium/Pilosidinium, Fromea, разнообразны пареодиниоидные. Стратиграфически важные таксоны: } \\
\text { Cribroperidinium granuligerum - появляется в верхнем келловее в Англиии и Германии [Woollam, Riding, 1983; Smelror, 1993], постоянные } \\
\text { находки и/или увеличение количества отмечаются с середины среднего оксфорда (основание зоны tenuiserratum) на севере Западной Европы } \\
\text { [Powel, 1992]. На юго-востоке Франции появляется в середине среднего оксфорда (а-зона bifurcates) [Courtinat, 1989]. } \\
\text { Fromea tornatilis - исчезает в верхней части среднего оксфорда (а-зона tenuiserratum) в Aнглии [Riding, 1991] и на Русской плите [Riding et } \\
\text { al., 1999]. В Западной Сибири этот вид не прослежен выше кровли келловея [Ilyina et al., 2005]. } \\
\text { Chytroeisphaeridia cerastes - постоянные находки наблюдаютя до кровли среднего оксфорда на севере Западной Eвропы [Powell, 1992] и на } \\
\text { Pусской плите [Riding et al., 1999]. }\end{array}$ \\
\hline $\begin{array}{l}\text { Слои с Heslertonia? } \\
\text { pellucida, } \\
\text { Senoniasphaera } \\
\text { jurassica, верхний } \\
\text { оксфорд без низов - } \\
\text { нижняя часть нижнего } \\
\text { кимериджа; мощность } \\
0,1 \text { м; впервые } \\
\text { установлены в разрезе } \\
\text { Нордвик в верхнем } \\
\text { оксфорде [Никитенко и } \\
\text { др., 2015а], по новым } \\
\text { данным верхняя часть } \\
\text { соответствует низам } \\
\text { кимериджа. } \\
\text { Распространение: север } \\
\text { Средней Сибири. }\end{array}$ & $\begin{array}{l}\text { Основание } \\
\text { определяется по } \\
\text { появлению } \\
\text { Senoniasphaera } \\
\text { jurassica, } \\
\text { Cassiculosphaeridia } \\
\text { magna, } \\
\text { Circulodinium } \\
\text { compta, кровля - по } \\
\text { появлению } \\
\text { Corсulodinium } \\
\text { inaffectum. В разрезе } \\
\text { Анабар границы не } \\
\text { прослежены. }\end{array}$ & 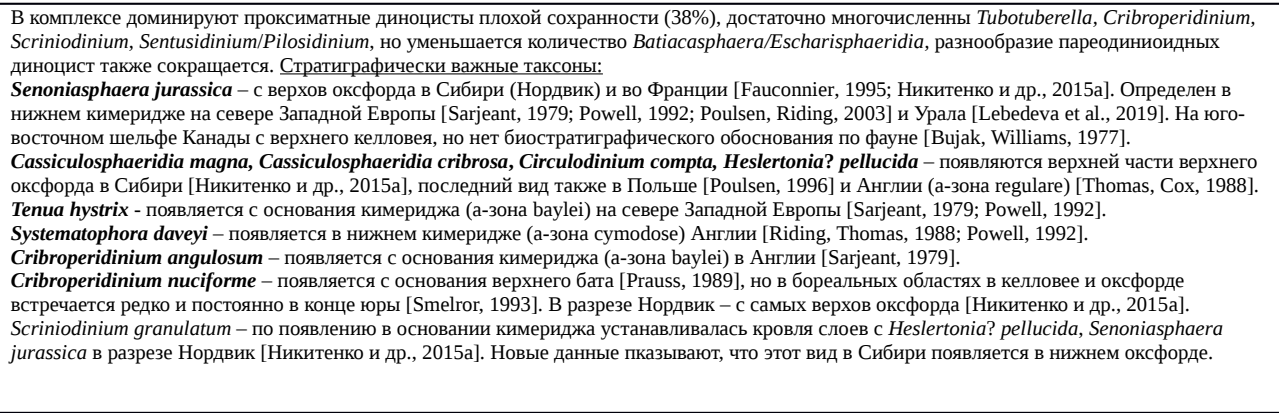 \\
\hline $\begin{array}{l}\text { Слои с Corculodinium } \\
\text { inaffectum, мощность } \\
0,1 \text { м; верхи нижнего - } \\
\text { низы верхнего } \\
\text { кимериджа; } \\
\text { соответствуют верхней } \\
\text { части слоев с } \\
\text { Scriniodinium granula- } \\
\text { tum, Corculodinium inaf- } \\
\text { fectum в разрезе } \\
\text { Нордвик [Никитенко и } \\
\text { др., 2015а]. } \\
\text { Распространение: север } \\
\text { Средней Сибири. }\end{array}$ & $\begin{array}{l}\text { Основание - по } \\
\text { появлению вида } \\
\text { индекса, кровля - } \\
\text { по появлению } \\
\text { Cribroperidinium? } \\
\text { ewardsii и } \\
\text { Trichodinium } \\
\text { erinaceoides } \\
\text { [Никитенко и др., } \\
\text { 2015а]. В разрезе на } \\
\text { р. Анабар границы } \\
\text { не прослежены. }\end{array}$ & 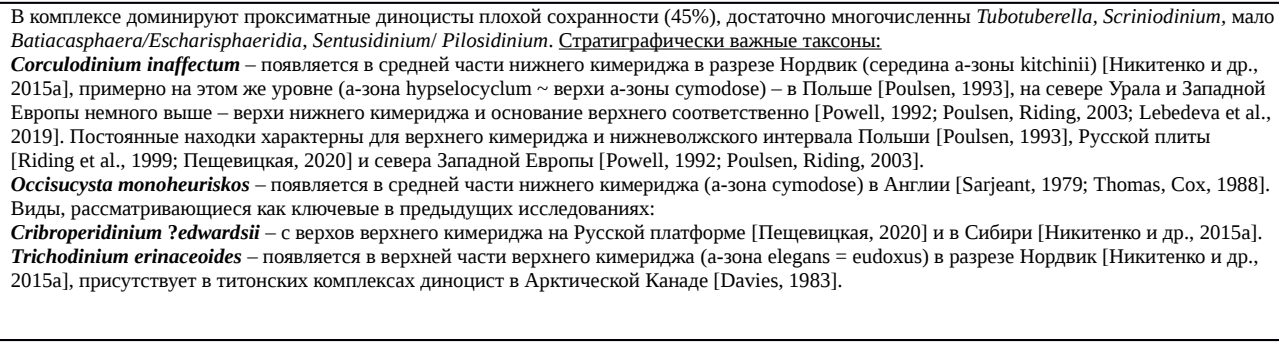 \\
\hline $\begin{array}{l}\text { Слои с } \\
\text { Cribroperdinium ? } \\
\text { edwardsii, Trichodinum } \\
\text { erinaceoides; мощность } \\
0,1 \text { м; верхи кимериджа } \\
\text { - низы нижневолжского } \\
\text { подъяруса; установлены } \\
\text { в разрезе Нордвик } \\
\text { [Никитенко и др., } \\
\text { 2015а]. } \\
\text { Распространение: север } \\
\text { Средней Сибири. }\end{array}$ & $\begin{array}{l}\text { Нижняя граница } \\
\text { проводится по } \\
\text { появлению } \\
\text { Cribroperi-dinium? } \\
\text { edwardsii, } \\
\text { Trichodinium } \\
\text { erinaceoides, } \\
\text { верхняя - по началу } \\
\text { акме Cometodinium, } \\
\text { в разрезе на р. } \\
\text { Анабар не } \\
\text { прослежены. }\end{array}$ & $\begin{array}{l}\text { В комплексе доминируют проксиматные диноцисты плохой сохранности (27\%), достаточно многочисленны Paragonyaulacysta, много } \\
\text { Batiacasphaera/Escharisphaeridia, Sentusidinium/ Pilosidinium. Стратиграфически важные таксоны: } \\
\text { Paragonyaulacysta? borealis - увеличение количества является дополнительным признаком слоев в разрезе Нордвик, особенно характено для } \\
\text { пограничного кимеридж-волжского интервала [Никитенко и др., 2015а]. } \\
\text { Виды, рассматривающиеся как ключевые в предыдущих исследованиях: } \\
\text { Cribroperidinium ?edwardsii и Trichodinium erinaceoides - см. описание предыдущих слоев с диноцистами. }\end{array}$ \\
\hline $\begin{array}{l}\text { Слои с Achomosphaera } \\
\text { neptuni, Bourkidinium; } \\
\text { мощность 1,5 м; } \\
\text { верхняя часть } \\
\text { средневолжского } \\
\text { подъяруса - самые } \\
\text { низы верхневолжского. } \\
\text { Слои с Bourkidinium, } \\
\text { установленные в } \\
\text { разрезе Оленек (север } \\
\text { Сибири), можно } \\
\text { рассматривать как } \\
\text { синоним [Nikitenko et } \\
\text { аl., 2018]. } \\
\text { Распространение: север } \\
\text { Средней Сибири. }\end{array}$ & $\begin{array}{l}\text { Нижняя граница в } \\
\text { разрезе на р. Анабар } \\
\text { определяется по } \\
\text { появлению } \\
\text { Achoтоsphaera } \\
\text { перtuni и } \\
\text { последнему } \\
\text { количественному } \\
\text { максимуму } \\
\text { Coтеtodinium, в } \\
\text { разрезе Нордвик - } \\
\text { по последнему } \\
\text { признаку и } \\
\text { появлению } \\
\text { Bourkidinium и } \\
\text { Biorbifera } \\
\text { johnewingii; верхняя } \\
\text { - по появлению } \\
\text { Gochteodina villosa. }\end{array}$ & 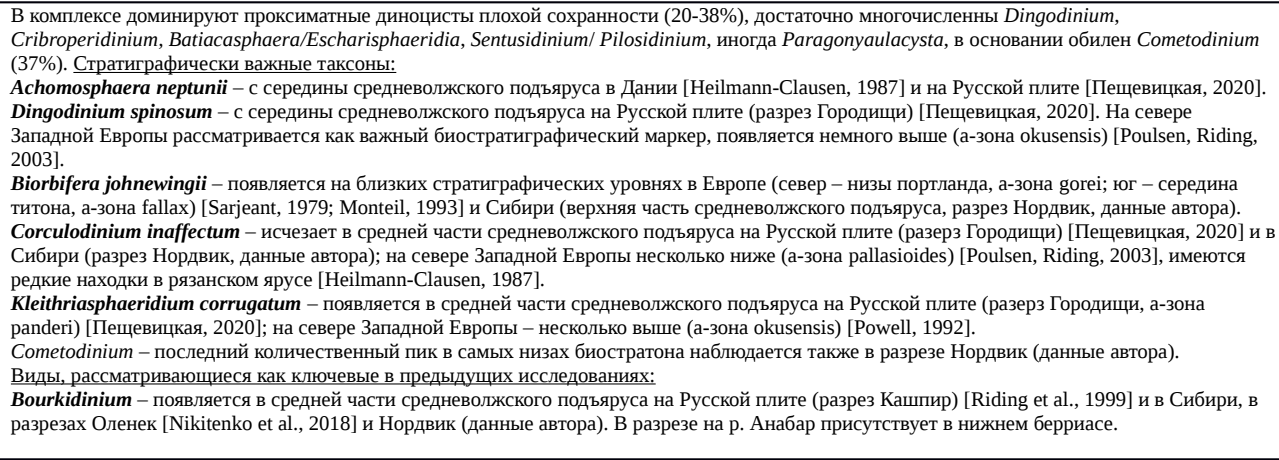 \\
\hline $\begin{array}{l}\text { Слои с Gochteodina } \\
\text { villosa; мощность 1 м; } \\
\text { средняя часть } \\
\text { верхневолжского } \\
\text { подъяруса. Впервые } \\
\text { установлены в разрезе } \\
\text { Оленек [Nikitenko et al., } \\
\text { 2018], прослеживаются } \\
\text { также в разрезе } \\
\text { Нордвик (материалы } \\
\text { автора). } \\
\text { Распространение: север } \\
\text { Средней Сибири. }\end{array}$ & $\begin{array}{l}\text { Основание - по } \\
\text { появлению } \\
\text { Gochteodi-nia } \\
\text { villosa; кровля - по } \\
\text { появлнию Cassi- } \\
\text { culosphaeridia reti- } \\
\text { culata в разрезе } \\
\text { Нордвик, на p. } \\
\text { Оленек - также по } \\
\text { появлению } \\
\text { Ocсіsucysta } \\
\text { tentorium, Batioladi- } \\
\text { nium varigranosum, } \\
\text { в разрезе на р. } \\
\text { Анабар не } \\
\text { прослежена. }\end{array}$ & 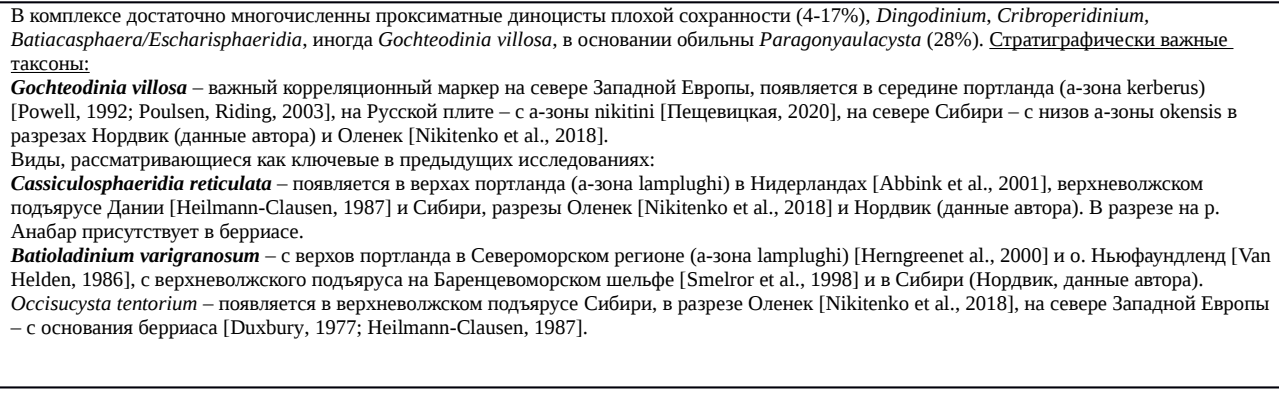 \\
\hline
\end{tabular}


Табл. 2. Спорово-пыльцевые биостратоны и их биостратиграфическая характеристика.

\begin{tabular}{|c|c|c|}
\hline Зоны, слои с СПК & Границы & Характерные черты комплекса и стратиграфически важные признаки \\
\hline $\begin{array}{l}\text { Слои 10б - Perotrilites } \\
\text { zonatoides, Leiotriletes } \\
\text { palescens, } \\
\text { Osmundacidites spp., } \\
\text { Periniopollenites } \\
\text { elatoides; мощность } 1 \\
\text { м; верхняя часть бата, } \\
\text { а-зоны іshmae-calyx } \\
\text { [Шурыгин и др., 2000; } \\
\text { Никитенко и др., 2013]. }\end{array}$ & $\begin{array}{l}\text { Нижняя не } \\
\text { прослежена, верхняя - } \\
\text { см. основание } \\
\text { палинозоны } 11 .\end{array}$ & $\begin{array}{l}\text { Установлены В.И. Ильиной [1985] на западном берегу Анабарской губы и прослежены на территории большинства фациальных } \\
\text { районов Сибири по появлению Uvaesporites cerebralis, Perotrilites zonatoides, Densoisporites velatus, Leiotriletes pallescens. Последние } \\
\text { три вида присутствуют в изученном разрезе, но отметим, что Perotrilites zonatoides имеeт широкое стратиграфическое распространение: } \\
\text { верхний плинсбах - нижний келловей [Ильина, 1985]. Первое появление Densoisporites velatus в Сибири отмечается с тоара, с } \\
\text { похолоданием в аалене-байосе вид исчезает и появляется вновь в верхней части бата [Ильина, 1985; Шурыгин и др., 2000; Смокотина, } \\
\text { 2006]. Важный признак спорово-пыльцевых комплексов бата - появление рода Gleicheniidites [Ильина, 1895; Шурыгин и др., 2000 и } \\
\text { др.]. Род характерен для западных районов Западной Сибири, а в центральных и северо-восточных отмечается редко [Лебедев, 1972; } \\
\text { Шейко, } 1980 \text { и др.]. В Восточной Сибири (Лено-Оленекий район) проблематичные споры глейхениевых (проиллюстрированные } \\
\text { морфотипы ближе к спорам диптерисовых папоротников) отмечаются с нижней юры, типичные формы появляются в бате (0,3\%) } \\
\text { [Короткевич, 1963]. В Вилюйской синеклизе - с нижнего мела [Болховитина, 1959; Фрадкина, 1967]. На р. Анабар в бате глейхениевые } \\
\text { есть, но род Gleicheniidites не обнаружен. }\end{array}$ \\
\hline $\begin{array}{l}\text { Палинозона } 11 \text { - } \\
\text { Суаthidites australis, } \\
\text { Classopollis, } \\
\text { Osmundacidites spp., } \\
\text { Kluckisporites } \\
\text { variegatus, } \\
\text { Microlepidites sp.; } \\
\text { мощность 0.3 м; } \\
\text { нижний келловей, а- } \\
\text { зоны еlatmae-durum } \\
\text { [Шурыгин и др., 2000; } \\
\text { Никитенко и др., 2013]. }\end{array}$ & $\begin{array}{l}\text { Нижняя по } \\
\text { увеличению } \\
\text { количества } \\
\text { Classopollis (в разрезе } \\
\text { Анабар с единичных } \\
\text { находок до } 3 \% \text { ), } \\
\text { верхняя не } \\
\text { прослежена. }\end{array}$ & $\begin{array}{l}\text { Установлена В.И. Ильиной на западном и восточном берегах Анабарской губы и о-ве Бегичев, прослежена в Западной Сибири в Обь- } \\
\text { Иртышском междуречье и Шаимском районе, а также в Канско-Ачинском бассейне по регулярному присутствию Classopollis, } \\
\text { Microlepidites crassirimosus, Kiukisporites variegatus и исчезновению крупных спор Perotrilites [Ильина, 1985; Шурыгин и др., 2000]. } \\
\text { Новые данные и анализ литературы показывают, что увеличение количества Classopollis - наиболее надежный признак. } \\
\text { Прослеживается как в Восточной, так и в Западной Сибири, но выражен по-разному: от 2-3\% в бате до 5-7\% в нижнем келловее в } \\
\text { западных и центральных районах Западной Сибири, от единичных находок до 3-5\% на севере, от отсутствия до появления в Вилюйской } \\
\text { синеклизе [Фрадкина, 1967; Лебедев, 1972; Шейко, 1980; Пуртова, Игнатова 1987; Костеша и др., 1991 и др.]. Со средней части келловея } \\
\text { количество Classopollis может увеличиваться значительно: до 24-28\% в западных и центральных районах Западной Сибири и 10-17\% на } \\
\text { севере и северо-востоке [Лебедев, 1972; Комплексные..., 1978; Шейко, Шатова, 1987; Шатова, 1994; и др.]. По данным В.И. Ильиной } \\
\text { [1985] значительное увеличение количества Classopollis (до 10\%) также наблюдается не с основания палинозоны, а в ее верхней части. } \\
\text { Остальные признаки менее надежны. Морфотип, определяемый советскими палинологами как Microlepidites сrassirimоsus, по } \\
\text { зарубежной классификации соответствует виду Dictyорhyllidites еquiexinus, который распространен как в нижней и средней юре, так и } \\
\text { нижнем мелу [Filatoff, 1975; Srivastava, } 1987 \text { и др.]. Первое появление Klukisporites variegatus в Сибири отмечается с тоара, с } \\
\text { похолоданием в аалене-байосе вид исчезает и появляется вновь в келловее [Ильина, 1985; Шурыгин и др., 2000]. Новые данные } \\
\text { показывают, что он может присутствовать и в бате (рис. 6). Род Perotrilites в Сибири достаточно редок, отмечен с верхнего плисбаха по } \\
\text { келловей [Ильина, 1985]. }\end{array}$ \\
\hline $\begin{array}{l}\text { Слои c Gleicheniidites } \\
\text { senonicus; мощность } 4 \\
\text { м; устанавливаются } \\
\text { впервые - средняя } \\
\text { часть оксфорда. }\end{array}$ & $\begin{array}{l}\text { Нижняя - условно по } \\
\text { появлению и } \\
\text { регулярному } \\
\text { присутствию } \\
\text { Gleicheniidites } \\
\text { senonicus, верхняя см. } \\
\text { ниже }\end{array}$ & $\begin{array}{l}\text { Важный признак - регулярное присутсвие Gleicheniidites senonicus на фоне доминирования мешковой пыльцы голосеменных. Отметим, } \\
\text { что в изученном разрезе образцы из верхней части келловея и низов оксфорда отсутствуют, поэтому нижняя граница палиностратона } \\
\text { проводится условно. Литературные данные показывают, что присутствие Gleicheniidites senonicus может наблюдаться и в более низких } \\
\text { горизонтах: на территории Сибири редкие находки этого вида отмечаются с верхов бата, регулярное присутствие - с келловея, но } \\
\text { точный уровень не указывается [Ильина, 1985]. }\end{array}$ \\
\hline $\begin{array}{l}\text { Слои с Trilobosporites; } \\
\text { мощность } 2,1 \text { м; } \\
\text { устанавливаются } \\
\text { впервые - верхняя } \\
\text { часть оксфорда - низы } \\
\text { кимериджа. }\end{array}$ & $\begin{array}{l}\text { Нижняя по появлению } \\
\text { Trilobosporites asper, } \\
\text { верхняя не } \\
\text { прослежена. }\end{array}$ & $\begin{array}{l}\text { Важный признак - появление бугорчатых спор схизейных, что также наблюдается в среднем оксфорде (а-зона densiplicatum) на } \\
\text { Североморском шельфе [Аbbink, 1998; др.]. По данным В.И. Ильиной [1985] эти морфотипы спорадически отмечаются в нижнем } \\
\text { оксфорде, однако в таблице стратиграфического распространения их появление показано с волжского яруса. Есть данные о присутствии } \\
\text { Trilobosporites asper в верхней части келловея Прибалтики [Васильева, 1973], но следует учитывать, что некоторые авторы } \\
\text { рассматривали этот вид в составе рода Maculatisporites и включали в него формы с шагреневой и тонкопунктированной скульптурой, } \\
\text { сходные по морфологии со спорами циатейных (Cyathidites punctatus) [Споры..., 1971]. Важный признак верхнего оксорда - } \\
\text { появление ребристых спор схизейных и новых видов среди бугорчатых морфотипов, что прослежено в Западной Европе, Северной } \\
\text { Африке и Австралии [Batten, 1996; Herngreen et al., 2000; Sajjadi, Playford, 2002; Schrank, 2010]. В Сибири (разрез Нордвик) это } \\
\text { позволило установить слои с Trilobosporites (Impardecispora) gibberulum, Ornamentifera echinata (верхняя часть верхнего оксфорда - } \\
\text { низы кимериджа) [Никитенко и др., 2015a]. На p. Анабар T. gibberulum и ребристые споры схизейных появляются выше, и слои не } \\
\text { прослежены, что может быть связано с недостаточным опробованием верхней части оксфорда и низов кимериджа, так как на этот } \\
\text { интервал здесь приходится размыв. }\end{array}$ \\
\hline $\begin{array}{l}\text { Слои с Podocarpidites } \\
\text { proximus; мощность 0,5 } \\
\text { м; верхняя часть } \\
\text { верхнего кимериджа - } \\
\text { нижневолжский } \\
\text { подъярус [Никитенко и } \\
\text { др., 2015]. } \\
\text { Распространение: север } \\
\text { Средней Сибири. }\end{array}$ & $\begin{array}{l}\text { Нижняя - по } \\
\text { появлению } \\
\text { Родосагрidites } \\
\text { proхітиз, верхняя - см. } \\
\text { следующие слои, в } \\
\text { разрезе Анабар не } \\
\text { прослежены. }\end{array}$ & $\begin{array}{l}\text { Слои с Cicatricosisporites perforatus, Selaginella utriculosa, Podocarpidites proximus установлены в разрезе Нордвик [Никитенко и др., } \\
\text { 2015]. Здесь изменено название биостратона по наиболее устойчивому признаку, позволяющему проводить корреляцию. Появление } P \text {. } \\
\text { proximus в верхней части верхнего кимериджа в разрезе Нордвик откалибровано относительно последовательностей аммонитов, } \\
\text { диноцист и фораминифер. Вид также отмечается в спорово-пыльцевом комплексе келловея-кимериджа (уровень появления не указан) в } \\
\text { Жиганском районе Якутии [Фрадкина, 1967] и нижневолжском подьярусе на севере Сибири (р. Оленек) [Nikitenko еt аl., 2018]. Кровля } \\
\text { биостратона в разрезе Нордвик не была установлена. Появление Selaginella utriculosa в разрезе Нордвик зафиксироано в верхнем } \\
\text { кимеридже [Никитенко и др., 2015]. В.И. Ильина также отмечала вид как характерный для этого интервала [Шурыгин и др., 2000]. } \\
\text { Однако анализ литературных данных показывает, что он может встречаться в келловее [Стратиграфо-палеонтологическая..., 1972; } \\
\text { Пуртова, Игнатова, 1987; Смокотина, 2006]. }\end{array}$ \\
\hline $\begin{array}{l}\text { Слои с } \\
\text { Cicatricosisporites } \\
\text { anglicanalis, } \\
\text { Trilobosporites } \\
\text { valanjinensis; мощность } \\
2 \text { м; устанавливаются } \\
\text { впервые - средняя } \\
\text { часть волжского яруса }\end{array}$ & $\begin{array}{l}\text { Нижняя - по } \\
\text { появлению видов- } \\
\text { индексов, верхняя - } \\
\text { см. следующие слои. }\end{array}$ & $\begin{array}{l}\text { По данным Г. Дорхофера [Dorhofer, 1979] на севере Западной Европы Trilobosporites valanjinensis появляется в верхней части } \\
\text { кимериджа sensu anglico (палинозона II, коррелируется с палинозоной A [Norris, 1969] и примерно соответствует средней части } \\
\text { волжского яруса). Этот вид также присутствует в средне- и верхневолжском подъярусах в центральных и северных районах Западной } \\
\text { Сибири [Глушко, Пуртова, 1980]. Постоянное присутствие Cicatricosisporites anglicanalis характерно для берриаса [Dorhofer, 1979]. } \\
\text { Однако в разрезе Нордвик в середине волжского яруса появляется другой вида этого рода с перфорацией на ребрах Cicatricosisporites } \\
\text { perforatus, [Никитенко и др., 2015]. На р. Анабар эти морфотипы появляются выше, видимо, из-за отсутствия образцов в переходной } \\
\text { нижне-средневолжской части разреза. Для средней части волжского яруса характерно постепенное увеличение разнообразия } \\
\text { бугорчатых и ребристых спор схизейных. }\end{array}$ \\
\hline $\begin{array}{l}\text { Слои с Cicatricosi- } \\
\text { sporites exilioides; } \\
\text { мощность } 2 \text { м; } \\
\text { устанавливаются } \\
\text { впервые - низы } \\
\text { берриаса [Nikitenko et } \\
\text { al., 2018]. } \\
\text { Pаспространение: север } \\
\text { Средней Сибири. }\end{array}$ & $\begin{array}{l}\text { Нижняя - по } \\
\text { появлению } \\
\text { Cicatricosispori-tes } \\
\text { exilioides, верхняя - } \\
\text { см. следующие слои. }\end{array}$ & $\begin{array}{l}\text { Ранее в разрезе на р. Оленек были установлены слои с Aequitriradites spinulosus, Cicatricosisporites exilioides в верхах волжского и низах } \\
\text { берриасского ярусов [Nikitenko et al., 2018]. Слои с Cicatricosisporites exilioides Анабарского разреза соответствуют их верхней части: в } \\
\text { обоих разрезах вид Cicatricosisporites exilioides появляется в приграничных волжско-берриасских слоях. С берриаса этот вид также } \\
\text { отмечается на территории Западной и Восточной Европы [Dorhofer, 1977; Воронова, 1984], Северной Америки [Вurden, Hills, 1989] и и } \\
\text { Дальнего Востока [Маркевич, 1995]. Для комплекса характерно дальнейшее увеличение разнообразия и количества бугорчатых и } \\
\text { ребристых спор схизейных. }\end{array}$ \\
\hline $\begin{array}{l}\text { Слои с Cicatricosi- } \\
\text { sporites ludbrockiae, } \\
\text { Taxodiaceaepollenites } \\
\text { (KSP1); мощность } 3 \text { м; } \\
\text { верхняя часть берриаса } \\
\text { (с кровли а-зоны } \\
\text { sibiricus) - самые низы } \\
\text { валанжина } \\
\text { [Пещевицкая, 2000; } \\
\text { Nikitenko et al., 2018]. } \\
\text { Распространение: север } \\
\text { Западной и Средней } \\
\text { Сибири }\end{array}$ & $\begin{array}{l}\text { Нижняя - по } \\
\text { появлению таконов- } \\
\text { индексов; верхняя - по } \\
\text { появлению } \\
\text { Cicatricosisporites } \\
\text { minor, Rousiesporites } \\
\text { laevigatus, Pilosispori- } \\
\text { tes parvispinosus и } \\
\text { увеличению } \\
\text { разнообразия и } \\
\text { количества ребристых } \\
\text { и бугорчатых спор } \\
\text { схизейных, на р. } \\
\text { Анабар не прослежена. }\end{array}$ & 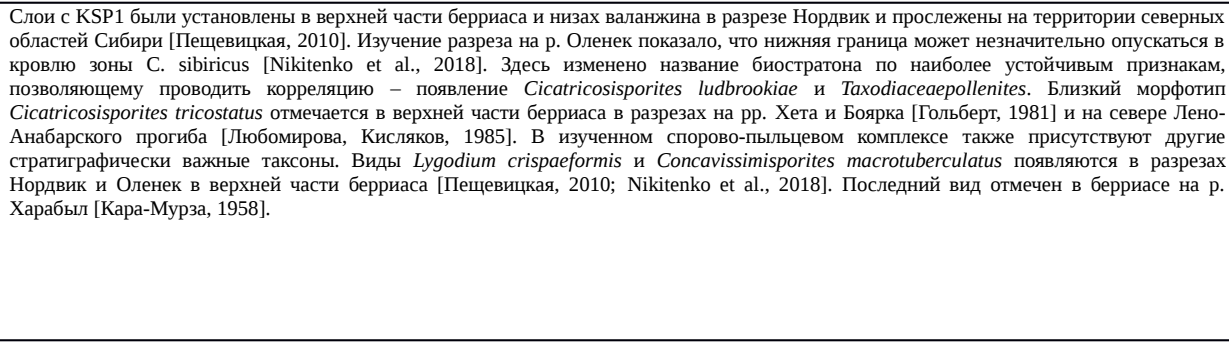 \\
\hline
\end{tabular}




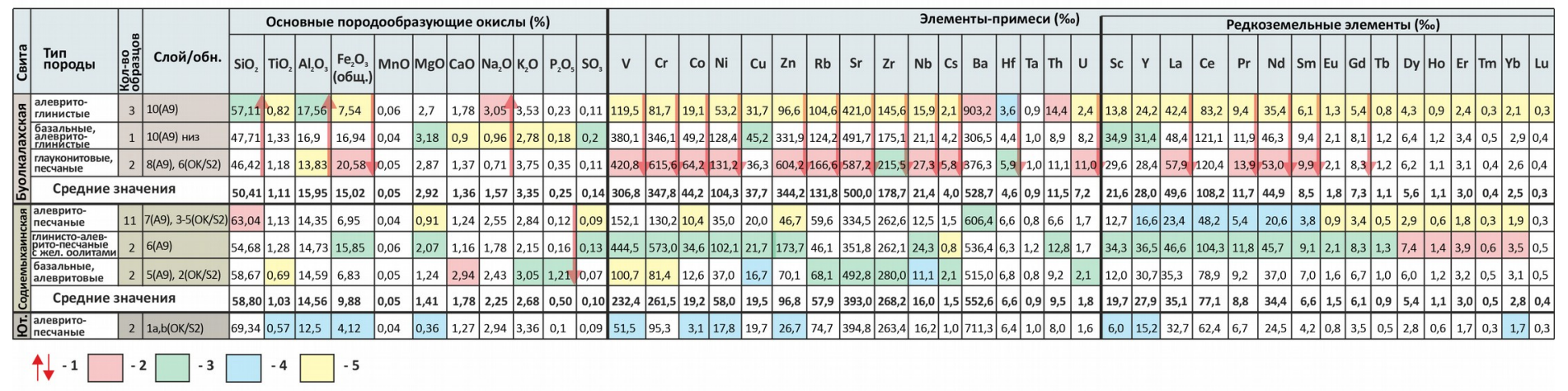

Табл. 3. Среднее содержание породообразующих окислов, элементов-примесей (с редкоземельными элементами). 


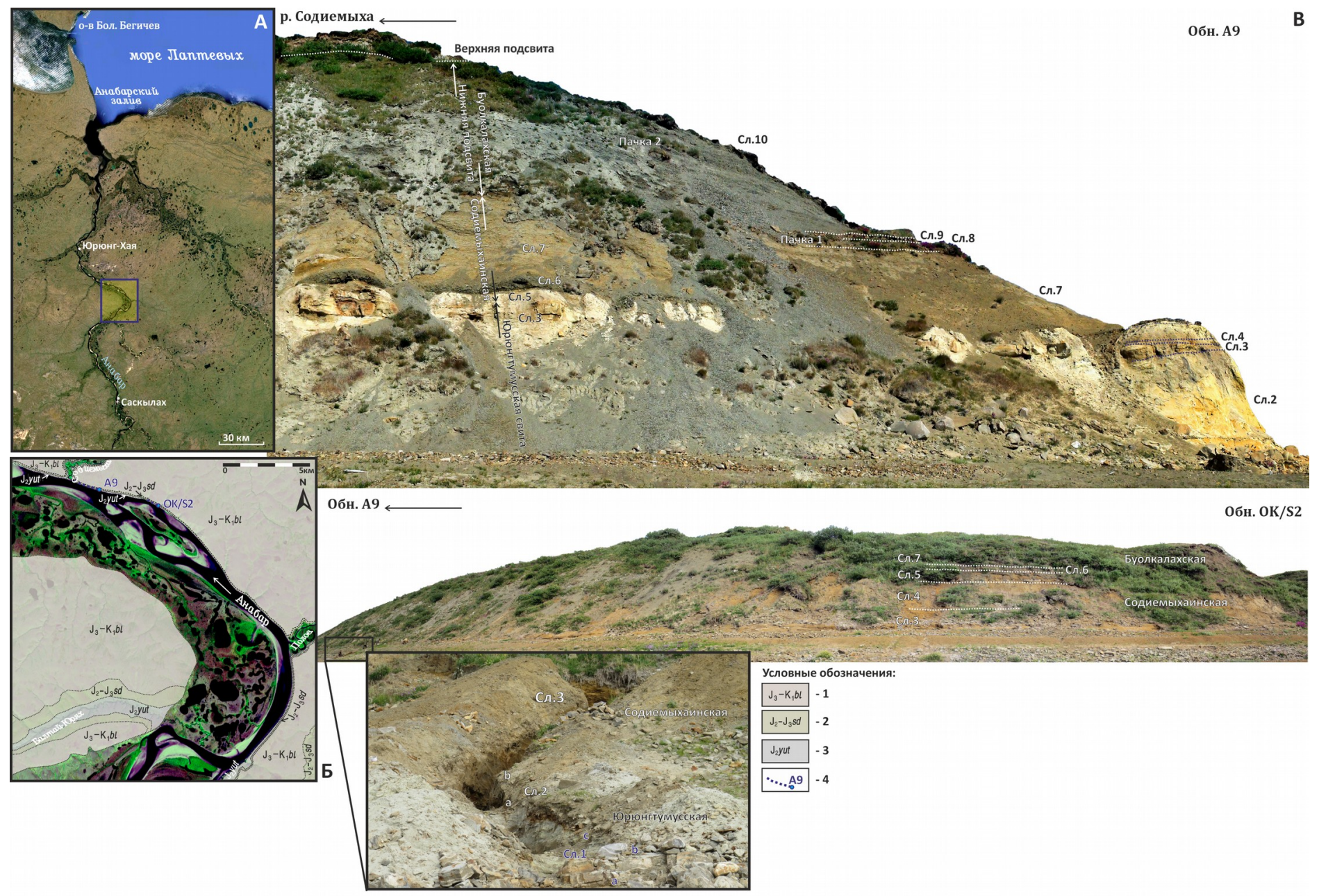

Рис. 1. Положение изученных разрезов средней юры - низов мела на р. Анабар (А) на геологической карте (Б) по [Духанин, 1976а, б] с изменениями и уточнениями и панорамный вид естественных выходов A9 и OK/S2. 


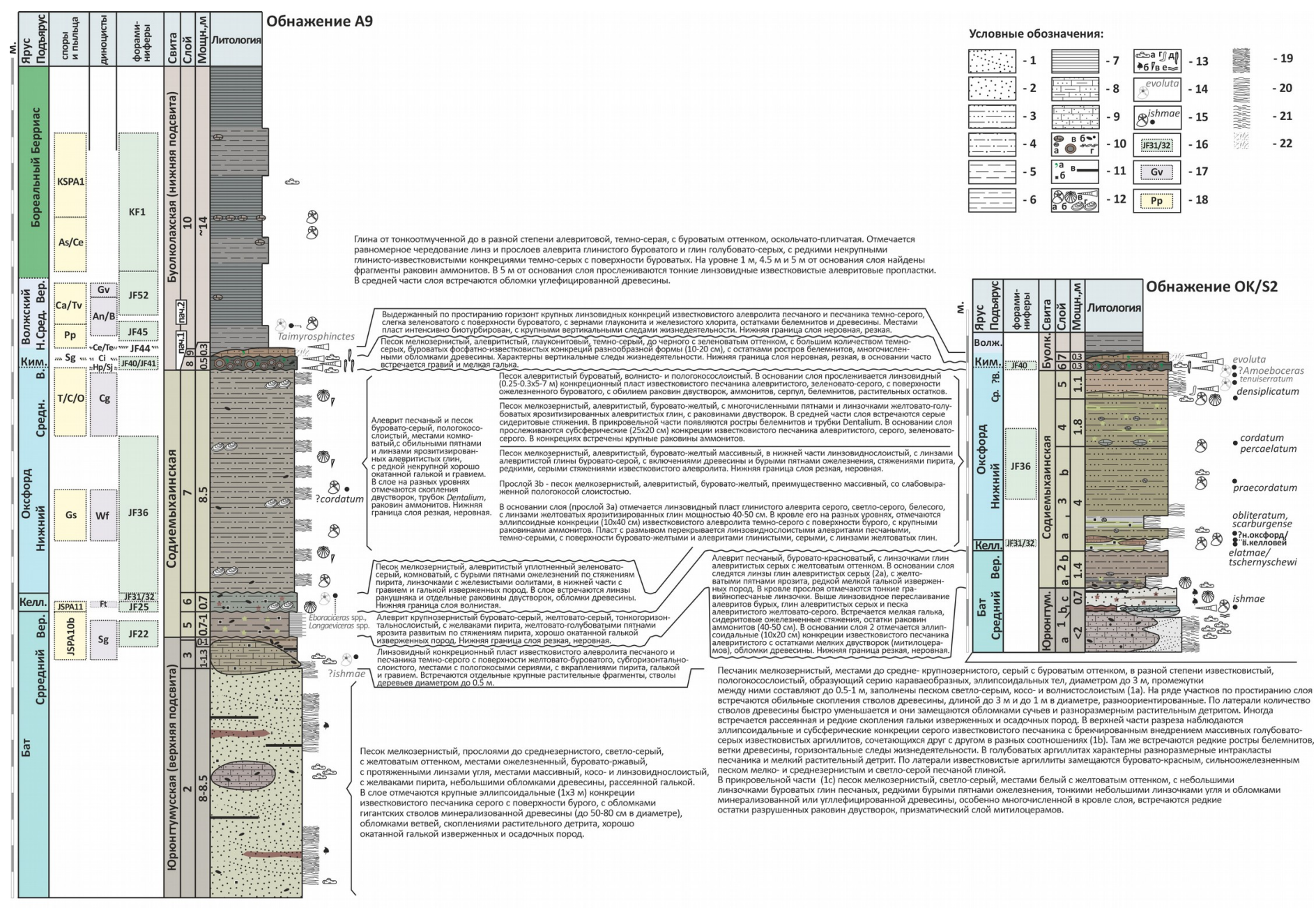

Рис. 2. Послойная характеристика строения разрезов A9 и OK/S2 верхов юрюнгтумусской, содиемыхаинской и низов буолкалахской свит 


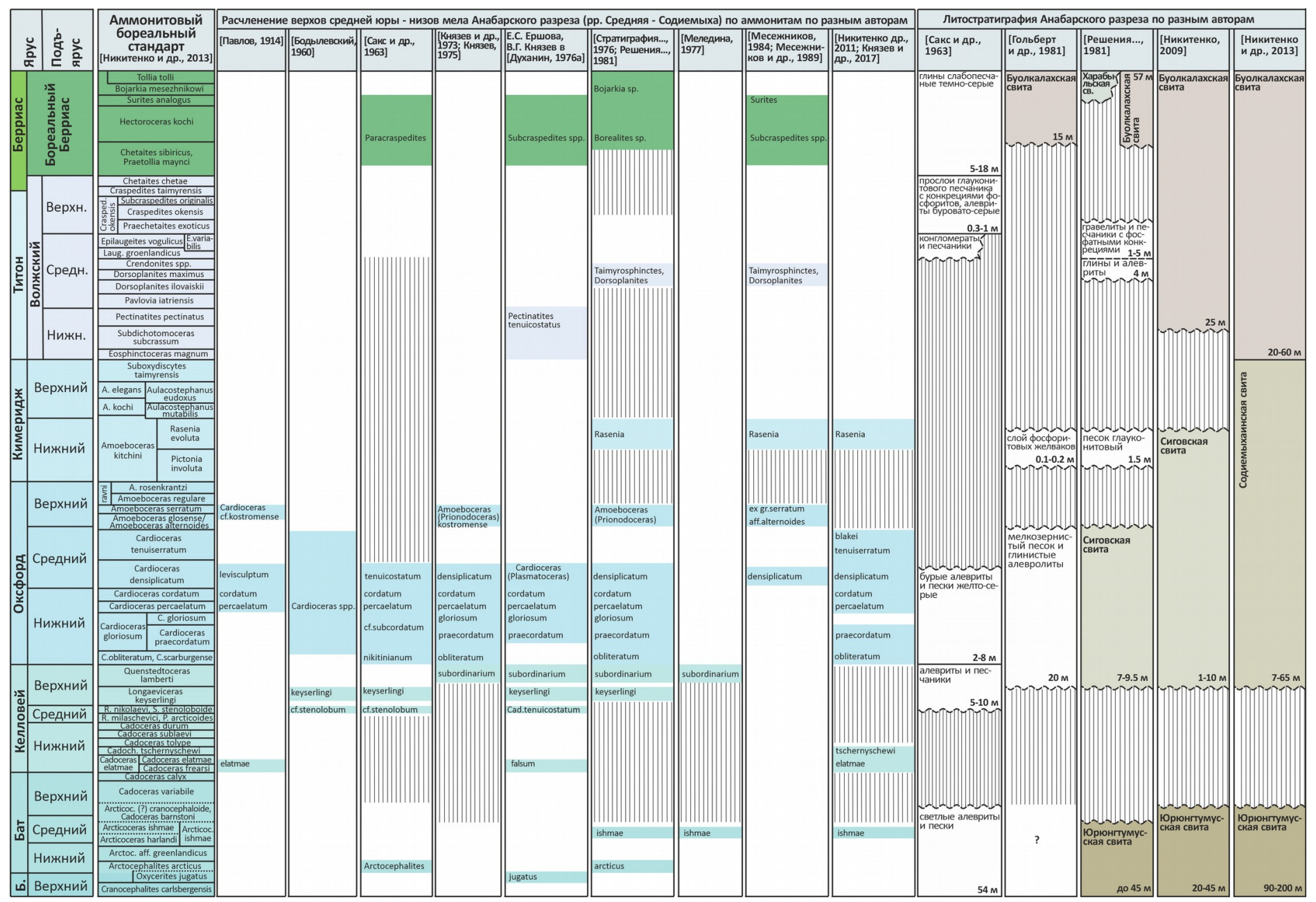

Рис. 3. Эволюция взглядов на биостратиграфическое (аммониты) и литостратиграфическое расчленение разрезов р. Анабар. 


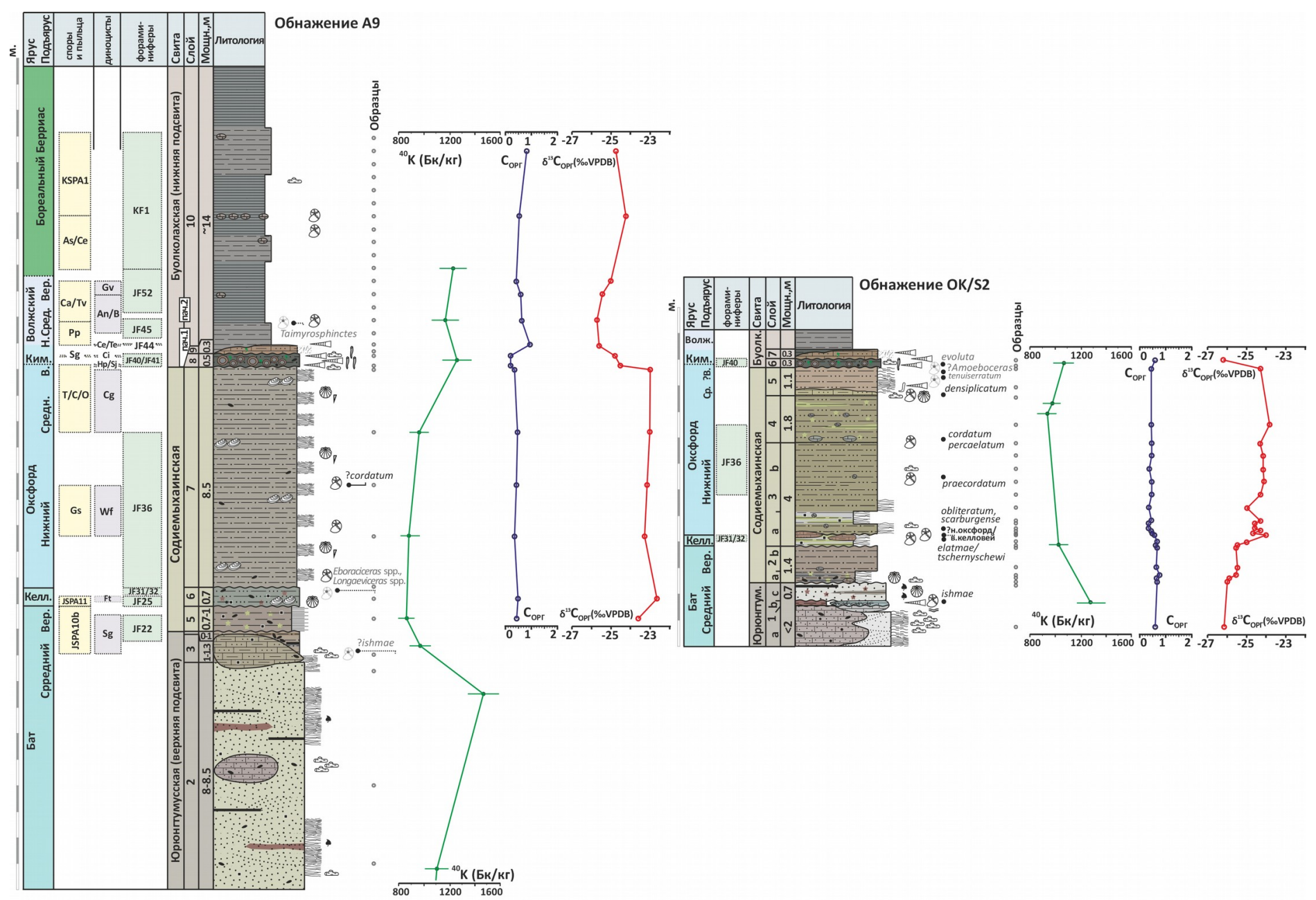

Рис. 4. Био- и литостратиграфическое расчленение разрезов верхов юрюнгтумусской, содиемыхаинской и низов буолкалахской свит в обнажениях A9 и OK/S2 и вариации геохимических параметров. 


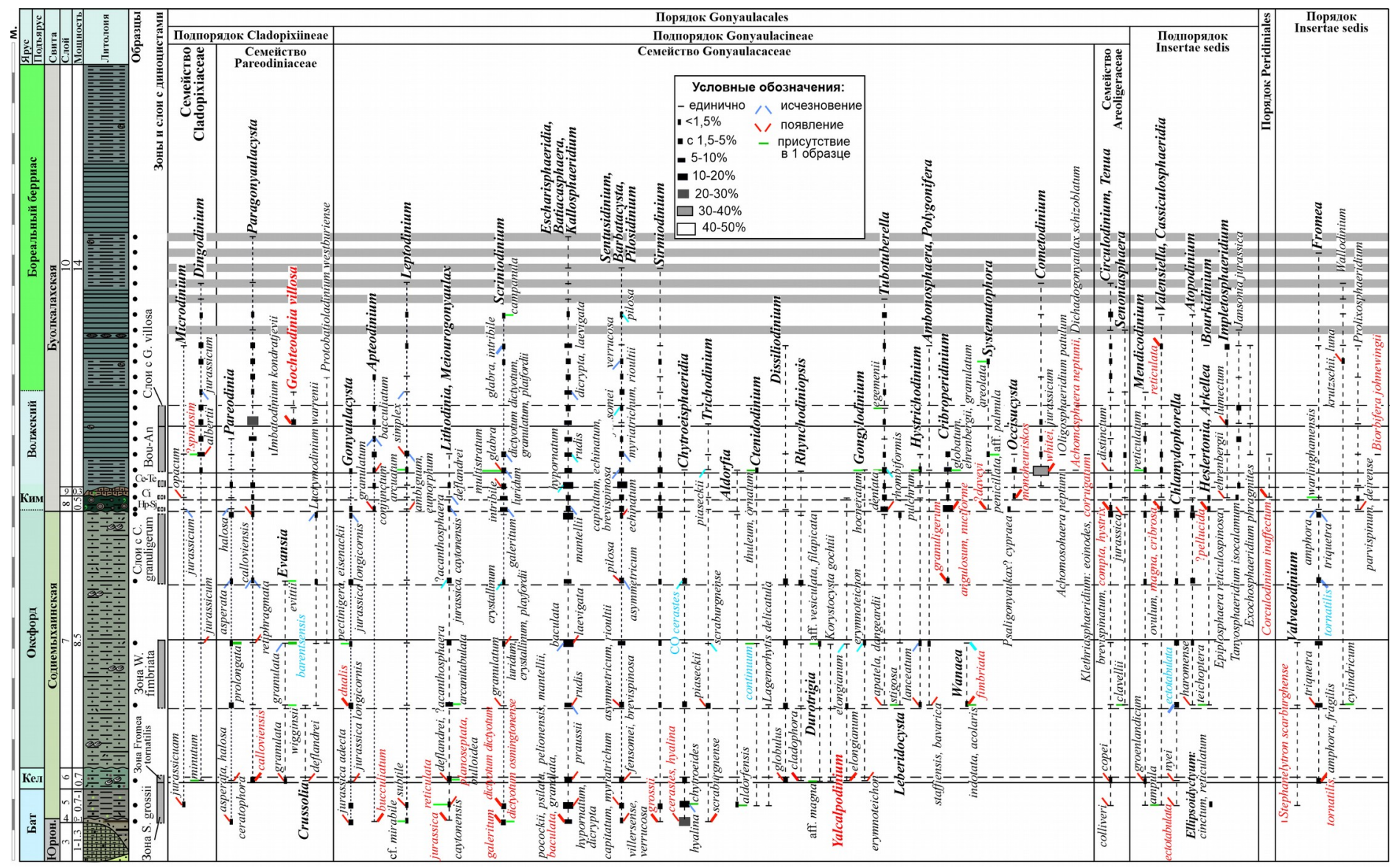

Рис. 5. Распределение основных таксонов диноцист в бате - низах бореального берриаса разреза А9. 


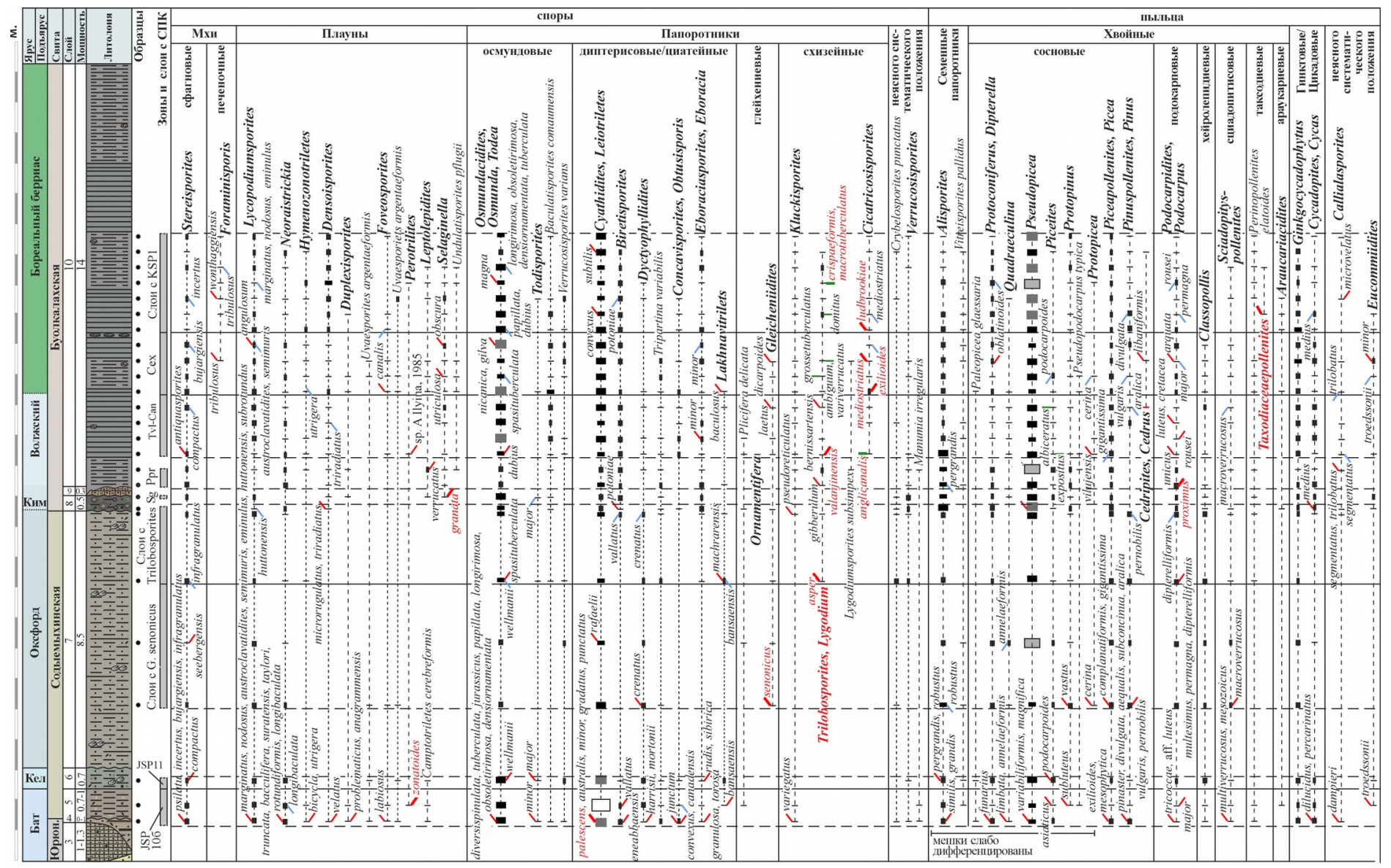

Рис. 6. Распределение основных таксонов спор и пыльцы в бате - низах бореального берриаса разреза А9 


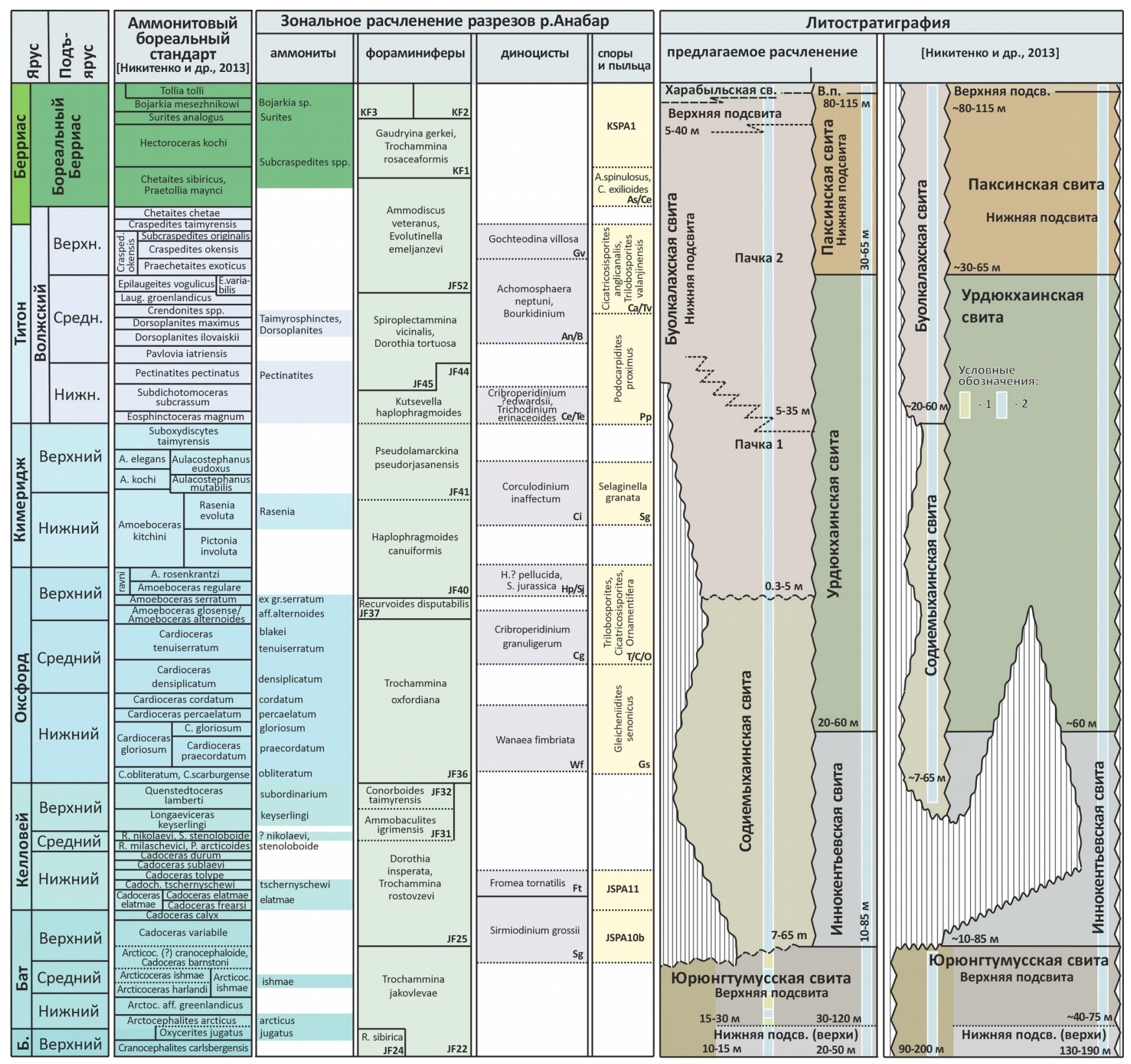

Рис. 7. Стратиграфическая схема верхов бата-низов бореального берриаса бассейна р.Анабар 


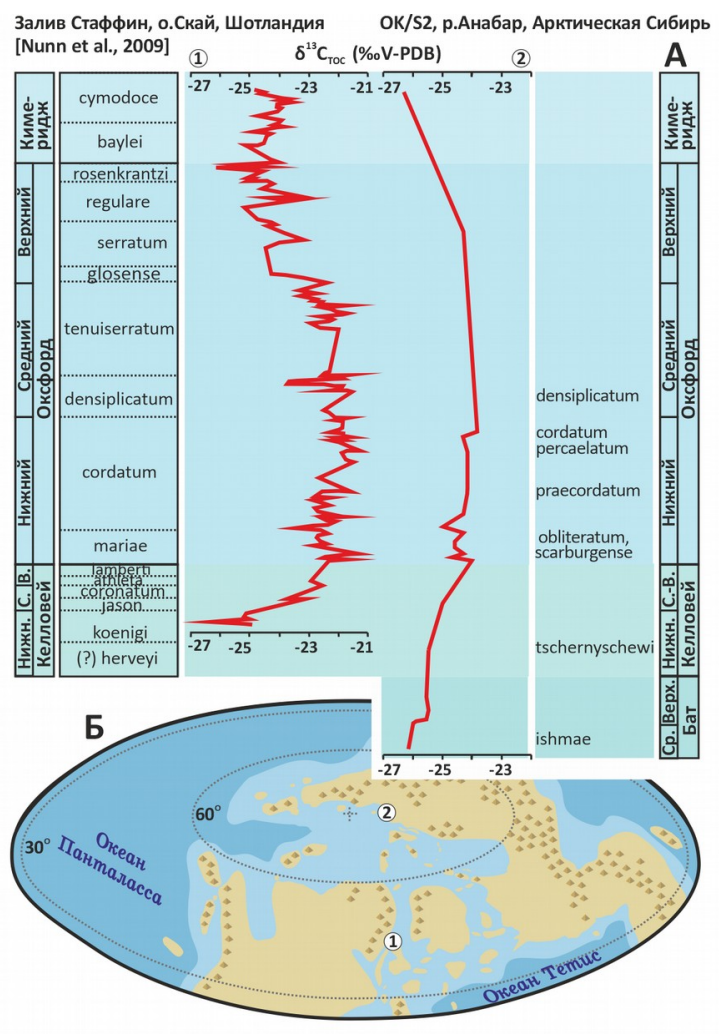

Рис. 8. Сравнение вариаций значений $\delta^{13} \mathrm{C}_{\text {орг. }}$ в разрезах верхов средней и верхней юры залива Стаффин, о-в Скай, Шотландия [Nunn et al., 2009] (1) и р.Анабар (2) (A) и глобальная палеогеография Северного Полушария в конце поздней юры и начале мела (Б) (палинспастические реконструкции, по [Scotese, 2011] с изменениями). 